\title{
Paleomagnetic and geochemical record from cores from the Sea of Marmara, Turkey: Age constraints and implications of sapropelic deposition on early diagenesis
}

\author{
L. Drab ${ }^{\text {a,* }}$, J. Carlut ${ }^{\text {b }}$, A. Hubert-Ferrari ${ }^{\text {c }}$, P. Martinez ${ }^{\text {d }}$, G. LePoint ${ }^{c}$, M. El Ouahabi ${ }^{\text {c }}$ \\ a ENS - 24, rue Lhomond, 75005 Paris, France \\ ${ }^{\mathrm{b}}$ Institut de Physique du Globe de Paris - Sorbonne Paris cite, Univ. Paris Diderot, UMR 7154 CNRS, F-75005 Paris, France \\ ${ }^{\mathrm{c}}$ Université de Liège - Allée du 6 août, Sart Tilman, B-4000 Liège, Belgium \\ ${ }^{\text {d }}$ UMR CNRS 5805 EPOC - Allée Geoffroy St Hilaire, 33615 Pessac Cedex, France
}

\section{A R T I C L E I N F O}

\section{Article history:}

Received 19 February 2014

Received in revised form 6 November 2014

Accepted 10 December 2014

Available online 18 December 2014

\section{Keywords:}

Marmara Sea

Sapropels

Early diagenesis

Paleomagnetism

\begin{abstract}
A B S T R A C T
We present results of a multi-proxy analysis of two sediment cores from the Marmara Sea. The cores were analyzed using paleomagnetic and geochemical measurements. Two sapropels are documented in the last $11 \mathrm{kyr}$ and are recorded in several locations across the Marmara Sea. These two sapropels have contrasting magnetic properties. The magnetic record is affected by intense early diagenesis; the most recent upper sapropelic layer has low remanence and susceptibility values. A record of paleomagnetic inclinations could still be isolated above the diagenesis front and is compared with secular variation models. The lower sapropel is identified in the deep part of the oldest studied core (Klg07) and has distinct magnetic properties characterized by high remanence and susceptibility values. Using the magnetic properties it is possible to constrain bottom water ventilation and reconnection episodes between the Marmara Sea and the Black Sea following the sea level rise during the last glacial to inter-glacial transition.
\end{abstract}

(c) 2014 Elsevier B.V. All rights reserved.

\section{Introduction}

Centimeter scale dark organic-rich layers interbedded in marine pelagic sediments, are commonly reported in the Mediterranean area and are referred to as sapropels (Rohling and Hilgen, 1991; Cramp and O'Sullivan, 1999; Nijenhuis and de Lange, 2000). Sapropel occurrence is related to changes in the Earth's orbit and is preferentially associated with northern hemisphere insolation maxima (Lourens et al., 1996). The combination of two factors - increased primary productivity in surface waters and limited ventilation of bottom waters - favors production and preservation of organic matter in deep basins and are regarded as the main causes of sapropel formation. However, the balance between these two factors is a matter of debate (Cramp and O'Sullivan, 1999; De Rijk et al., 1999). Moreover, the relationship between successive sapropel deposition episodes in the Aegean, Tyrrhenian, Marmara and Black Seas is not clear because the occurrence and preservation of sapropel sequences exhibit notable differences even through the same basin (Higgs et al., 1994; Emeis et al., 1996). This complexity may be related to local intermittent re-ventilation episodes at the sediment/water interface throughout the sapropel deposition period (Casford et al., 2003).

\footnotetext{
* Corresponding author.

E-mail address: Idrab@ldeo.columbia.edu (L. Drab).
}

Sapropels can sometimes be identified visually (Emeis et al., 2000), but only multi-proxy analyses allow their unambiguous identification. Organic carbon content is the original defining criterion, the name sapropel is traditionally used when the amount of organic carbon $\left(\mathrm{C}_{\text {org }}\right)$ by weight is greater than $2 \%$, while the term sapropelic is used for similar deposits containing between $0.5 \%$ and $2 \% \mathrm{C}_{\text {org }}$ by weight (Kidd et al., 1978). It has also been shown that the concentration of bromine $(\mathrm{Br})$ and barium $(\mathrm{Ba})$ or ratios of barium over aluminum $(\mathrm{Ba} / \mathrm{Al})$, which reflect surface water productivity and/or terrigenous input, can be used to detect sapropels (Thomson et al., 1995; Van Santvoort et al., 1997; Nijenhuis and de Lange, 2000; Wehausen and Brumsack, 2000; Larrasoaña et al., 2006; Ziegler et al., 2008). However, post depositional redox alteration of organic matter can result in relocation of redox-sensitive elements and, in severe cases, of removal of almost all geochemical indicators associated with sapropels (Higgs et al., 1994; Thomson et al., 1995; Van Santvoort et al., 1997; Larrasoaña et al., 2006).

Insights into the detection and nature of sapropels can be provided by magnetic analysis. The intense anoxic diagenesis that occurs during and after deposition of these organic-rich layers strongly affects their magnetic properties (Langereis and Dekkers, 1999). A decrease in magnetization due to the reductive dissolution of (titano)-magnetite in anoxic sediments is a well-known phenomenon (Canfield and Berner, 1987) and is reported in some sapropel studies (Van Santvoort et al., 1997; Larrasoaña et al., 2003, 2006). In contrast, in other studies (Stoner et al., 1998; Roberts et al., 1999), remanence intensities of 
sapropels can be up to three orders of magnitude higher than those of underlying sediments. This property was first attributed to the creation of an "unknown" ferrimagnetic iron sulfide phase during diagenesis (Roberts et al., 1999). Recently, Reinholdsson et al. (2013) linked magnetic enhancement of laminated sapropels from the Baltic Sea to small single domain particles of greigite $\left(\mathrm{Fe}_{3} \mathrm{~S}_{4}\right)$ interpreted as relict magnetosoms of magnetotactic bacteria (MTB). These authors suggest that magnetic properties associated to bacterial greigite could be a good proxy for hypoxia. Larrasoaña et al., 2003, 2006 observed a characteristic inverse S-shaped stratigraphic variation of magnetic remanence in some sapropel-bearing intervals with high values above sapropels and low values within. They interpreted the high values as reflecting magnetite formation at a paleo-oxidation front above the sapropels due to re-oxygenation of bottom waters after sapropelic episodes. The low values below and within sapropels are interpreted to occur as a consequence of the presence of a dissolution front caused by the anoxic conditions prevailed at times of sapropel formation. Hence, the magnetic properties of sapropels can have contrasting characteristics, which may reflect their dependence on the strength of bottom water ventilation.

Based on Total Organic Carbon content measurements (TOC), two sapropels were recently reported in the Marmara Sea: a "lower" sapropel, aged 11.5 to 7 cal kyr (Çağatay et al., 1999, 2003; Vidal et al., 2010), and an "upper" sapropelic layer between 4.7 and $3.2 \mathrm{ka}$ (Çağatay et al., 1999; Tolun et al., 2002). We report here the results of environmental magnetic, paleomagnetic, organic carbon and geochemical data $\left(\delta^{13} C, \mathrm{C} / \mathrm{N}\right)$ obtained from two Holocene piston cores (Klg06 and Klg07) from the Marmara Sea. Detailed lithologic, radiocarbon dating, $\mathrm{Br}, \mathrm{Ca} / \mathrm{Ti}$ and magnetic susceptibility records for these cores have been presented by Drab et al. (2012) and were used to characterize and correlate the imprint of earthquake events across the western part of the Marmara Sea.

The primary goal of this study is to better characterize the magnetic and chemical properties of the two most recent sapropel levels in the Marmara Sea and to discuss their regional or local character. Using the magnetic properties, we attempt to place some new constraints on bottom water ventilation and the reconnection episodes between the Marmara Sea and the Black Sea following the sea level rise during the last glacial to inter-glacial transition.

\section{Geological setting}

The Marmara Sea is a pull-apart Basin $170 \mathrm{~km}$ long and $55 \mathrm{~km}$ wide located SW of Istanbul in NW Turkey (Fig. 1). The sea is crossed by the northern branch of the North Anatolian Fault (Barka and KadinskyCade, 1988; Armijo et al., 1999), which is an active strike-slip fault that ruptures in $\mathrm{M}>7$ earthquakes with a 300-year recurrence time (Stein et al., 1997; Rockwell et al., 2001) and slips with an average rate of $20 \mathrm{~mm} / \mathrm{yr}$ (McClusky et al., 2003). The northern part of the Marmara Sea is composed of three aligned fault-bounded extensional sub-basins named from west to east: The Tekirdağ, Central and Çınarcık Basins (Fig. 1, Armijo et al. (1999); Le Pichon et al. (2001); Armijo et al. (2002)). The basins, which have a maximum water depth of $1250 \mathrm{~m}$, are separated by two topographic ridges: the Western High and the Central High, which have water depths of $900 \mathrm{~m}$ and $600 \mathrm{~m}$ respectively. They are being filled with lacustrine and marine sediments (Okay et al., 1999; Çağatay et al., 2003) that are deposited partly as seismoturbidites (McHugh et al., 2006; Sarı and Çağatay, 2006; Beck et al., 2007; Drab et al., 2012; Campos et al., 2013).

During the last glacial period the Marmara Sea was isolated from the Aegean Sea but might have been connected at times with the Black Sea to form two joined fresh-water inner lakes (Çağatay et al., 2000). The existence of a westward-directed topset-to-foreset transition at the southern Bosphorus Strait exit supports the hypothesis of a general overflow from the Black Sea (Aksu et al., 1999, 2002). Following the post-glacial rise in sea level the three seas reconnected when the water level rose to the sill depths of the Dardanelles and Bosphorus Straits (Fig. 1). The timing and possible catastrophic nature of the reconnections have been a subject of debate (Ryan et al., 1997; Çağatay et al., 2000; Aksu et al., 2002; Major et al., 2006; Vidal et al., 2010). Recent analyses based on radiocarbon dating of gravity cores and $\delta^{18} \mathrm{O}$ isotopic measurements led Vidal et al. (2010) to propose the following chronology: the marine transgression accompanying the reconnection with the Mediterranean Sea through the Dardanelles Strait started at $14.7 \mathrm{ka}$ cal BP (Lambeck et al., 2007) and lasted $2 \mathrm{ka}$. The Black Sea then reconnected to the Mediterranean Sea through the Bosphorus Strait between 9 and 8 ka BP. Today, a two-layer flow is established in the Marmara Sea composed of a superficial low-salinity current from the Black Sea and a deeper counter current from the Aegean Sea (Besiktepe et al., 1994). Stratification of waters in the Marmara Sea is associated with a dissolved oxygen deficit in the bottom waters (Besiktepe et al., 1994). This favors preservation of a significant proportion of organic matter in sediments.

Several authors (Aksu et al., 2002; Tolun et al., 2002; Çağatay et al., 2003; Sperling et al., 2003; Vidal et al., 2010) have reported a lower sapropel in the Marmara Sea that was deposited roughly between 11.5 and 7 cal ka, after reconnection of the Marmara Sea with the Mediterranean Sea. This sapropel precedes but partly overlaps with the age of the S1 sapropel from the Central and Eastern Mediterranean Sea dated between 10.8 and $6.1 \mathrm{ka}$ cal BP (De Lange et al., 2008). The time lag between the Marmara and Mediterranean sapropels has led to variable names to the Marmara sapropels: $S 1_{\text {Marmara }}$ in Sperling et al. (2003) and M1 in Çağatay et al. (2000); Aksu et al. (2002) and KirciElmas et al. (2008). Synchronicity of the S1 level between the Eastern Mediterranean Sea and the Black Sea incursion has led some authors to suggest that S1 could have resulted of fresh-water influx at the time of reconnection (Çağatay et al., 2000; Kotthoff et al., 2008). Regardless, the role of the Black Sea remains unclear and the early occurrence of $S 1_{\text {Marmara/ }}$ 1 complicates the picture (Tolun et al., 2002). In addition, an upper sapropelic layer is identified between 4.7 and $3.2 \mathrm{ka} B P$ (Çağatay et al., 2000; Tolun et al., 2002); this layer may be only local, as it is not reported elsewhere.

\section{Materials and methods}

\subsection{Core description}

Kullenberg piston cores were recovered in the Marmara Sea during the Marmarascarps mission in 2002 (Fig. 1, Armijo et al. (2005)). The cores are 3 to $4.5 \mathrm{~m}$ long and sample the upper marine part of the Marmara Sea relatively close to the active strands of the North Anatolian Fault. We focus on the Klg06 and Klg07 cores from the Western High (Fig. 1), as described by Drab et al. (2012). These cores were selected because they are largely composed of hemipelagic sediments with only fine silt deposits and hence have probably not been subjected to major seismic reworking as is often the case in this seismically active area (Drab et al., 2012). Klg06 core was recovered at a water depth of $726 \mathrm{~m}$ while $\mathrm{Klg} 07$, located $15 \mathrm{~km}$ east of Klg06, was sampled at a water depth of $1065 \mathrm{~m}$ (Fig. 1). Cold seeps were found near Klg06 (Fornacciari, 2005; Zitter et al., 2008). Carbon isotopes dating indicates that Klg06 spans the last 7 ka BP over a sediment thickness of $3.8 \mathrm{~m}$ whereas Klg07, based on magnetic susceptibility correlation with a core from Vidal et al. (2010), likely records deposition since 11 ka BP in a 4 minterval (see Drab et al. (2012) for details).

To extend the scope of results from the Western High, we also present previously unpublished geochemical analyses from cores Klg03 and Klg04 in the Çınarcık Basin. These cores were recovered at water depths of $1240 \mathrm{~m}$ and $1206 \mathrm{~m}$, respectively, and are separated by $\sim 100 \mathrm{~km}$ from the Klg06 and Klg07 cores (Fig. 1-B). Based on ${ }^{14} \mathrm{C}$ measurements, Klg03 records $4 \mathrm{ka} \mathrm{BP}$ of sedimentation over a $3.75 \mathrm{~m}$ interval and Klg04 records $6.5 \mathrm{ka} \mathrm{BP}$ of sedimentation over $4.20 \mathrm{~m}$ interval. The 


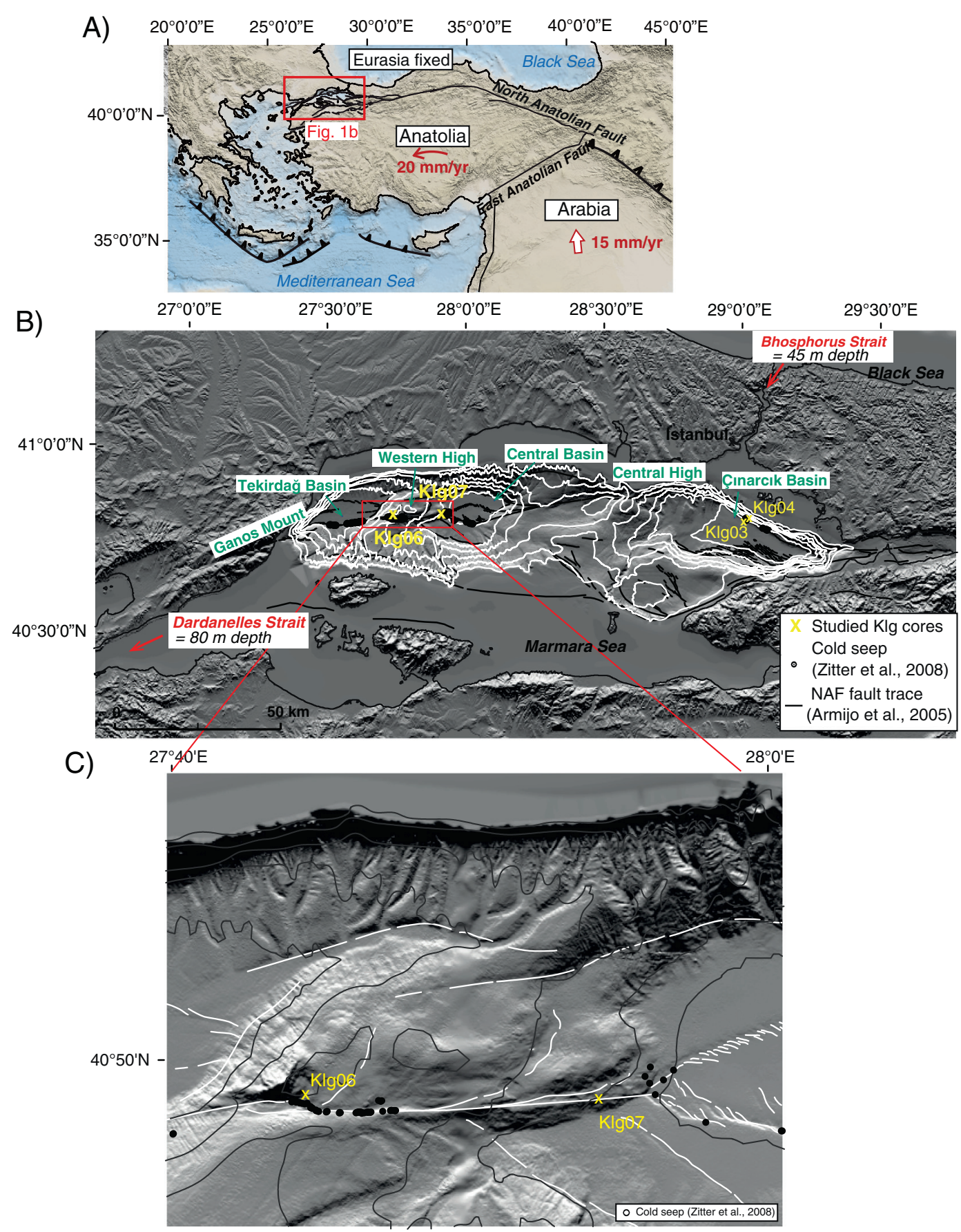

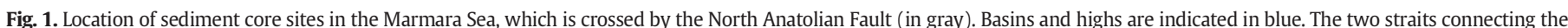

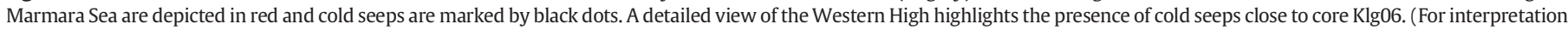
of the references to color in this figure legend, the reader is referred to the web version of this article.)

paleoseismological record of the two cores was presented by (Drab et al., 2014).

\subsection{Analytical Methods}

The cores were sampled continuously using $1.5 \mathrm{~m}$ u-channels. High-resolution X-ray images of cores were obtained with a Scopix system at the University of Bordeaux, France. The X-ray images were used to map the macroscopic occurrence of iron sulfides. TOC, $\mathrm{C} / \mathrm{N}$ ratios and $\delta^{13} \mathrm{C}$ were measured on decarbonized samples with a Vario Microcube CNS elemental analyzer coupled with a IRMS Isoprime 100 isotope ratio mass spectrometer at the University of
Liège, Belgium. Information regarding the origin of organic matter (OM) is given by $\mathrm{C} / \mathrm{N}$ ratios and $\delta^{13} \mathrm{C}$ data (Gearing et al., 1977; Likens et al., 1981; Meyers, 1994). Marine organic matter typically has $\delta^{13} \mathrm{C}$ values less negative than plant lands (respectively between -20 and -22 to about -27 ). In addition, terrestrial organic matter tends to have higher $\mathrm{C} / \mathrm{N}$ ratios (in the range of 15-30) than marine organic matter (ratios of about 7 to 10 (Hedges et al., 1997)) although this signature may be lost during diagenesis (Cowie and Hedges, 1994). In any cases, this parameter cannot be used alone as a criterion to detect sapropels. For example, some authors propose a predominantly terrigenous origin for the sapropel organic matter while others suggest a marine origin (Kroon et al., 1998). 
We also collected semi-quantitatively elemental concentration of $\mathrm{Br}$, $\mathrm{Ca}, \mathrm{Ti}$, and $\mathrm{Fe}$ using $\mathrm{X}$-ray fluorescence with energies of radiation of $10 \mathrm{keV}$ and $30 \mathrm{keV}$ on an Avaatech XRF core scanner at $5 \mathrm{~mm}$ stratigraphic intervals on all split cores at the University of Bordeaux. This non-destructive technique allows a continuous and high-resolution distribution of bulk elements intensities to be determined in counts per second. To compare elemental variations in the different cores we standardized all measurements to zero mean and unit variance. Ratios of elements were also used as they provide the most easily interpretable signal of relative changes in chemical composition (Pälike et al., 2001; Vlag et al., 2004; Bahr et al., 2005). We particularly focus on Br intensity, because solid phase $\mathrm{Br}$ is associated with marine organic matter and has been successfully used as a proxy for OM deposition (Ziegler et al., 2008). Variations in Fe intensity are exploited to look at possible iron depletion or enrichment. Finally, we use $\mathrm{Ca}$ /Ti ratio to correlate the different cores. Ca represents autochthonous marine productivity with respect to terrigenous input (Ti) (Fig. A.1; Bahr et al. (2005); Drab et al. (2012)). Drab et al. (2012) showed that changes in the Ca/Ti ratio in the Marmara Sea are widespread, synchronous and probably related to basin-wide environmental changes.

Magnetic susceptibility measurements, $\chi$, were made on the surface of split cores using a Bartington instruments MS2E sensor at $5 \mathrm{~mm}$ stratigraphic intervals at room temperature at the University of Bordeaux. Bulk magnetic susceptibility mainly reflects the ferrimagnetic mineral content. Minerals with the highest susceptibility are (titano-)magnetite

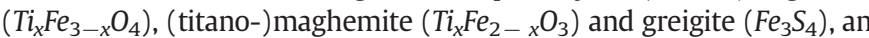
authigenic ferrimagnetic mineral that grows as a precursor to pyrite during diagenesis under sulfate-reducing conditions (O'Reilly, 1984; Dunlop and Özdemir, 1997; Roberts et al., 2011). The Natural Remanent Magnetization (NRM) and Anhysteretic Remanent Magnetization (ARM) were measured on $1.5 \mathrm{~m}$ long u-channel samples using a 2-GEnterprises horizontal cryogenic magnetometer at the paleomagnetic laboratory of the Institut de Physique du Globe de Paris (IPGP) and at the Laboratoire des Sciences du Climat et de l'Environnement (LSCE) laboratory at Gif-sur-Yvette, France. Measurements were made at $2 \mathrm{~cm}$ stratigraphic intervals. Data from the upper and lower $5 \mathrm{~cm}$ of each u-channel were excluded because of edge effects (Weeks et al., 1993). The NRM was progressively demagnetized using alternating field (AF) demagnetization at eleven steps up to a maximum peak field of $90 \mathrm{mT}$, which allowed isolation of the characteristic remanent magnetization (ChRM). ARM was imparted in a $90 \mathrm{mT}$ DC field with a superimposed direct field of $0.1 \mathrm{mT}$, which was then demagnetized at $20 \mathrm{mT}$ in order to remove the most viscous component. NRM intensity depends on the content and nature of ferrimagnetic minerals but also on past variations of Earth's magnetic field, whereas ARM only depends on content and nature of ferrimagnetic minerals.

The temperature dependence of magnetic susceptibility was measured either in an argon or oxygen atmosphere for ten representative samples in Klg07 using a CS3-KLY3 Kappabridge magnetic susceptibility meter at ENS-Paris. Heating was performed from room temperature to $680{ }^{\circ} \mathrm{C}$. In addition, and again for 10 selected samples from Klg07, unblocking temperature spectra were determined from stepwise thermal demagnetization of the saturation isothermal remanent magnetization (SIRM). The samples were exposed to a $1 \mathrm{~T}$ field and were then demagnetized in 17 successive steps from $120^{\circ} \mathrm{C}$ to $680^{\circ} \mathrm{C}$.

Low and high coercivity minerals contributions were evaluated using the SIRM and S-ratio by imparting a $1 \mathrm{~T}$ isothermal remanent magnetization IRM $\left(I_{1}\right)$ followed by a 0.3 T backfield IRM $\left(I_{0.3}\right)$. Measurements were performed using an electromagnet and an AGICO JR6 spinner magnetometer at IPGP. The S-ratio was then calculated as $S=\left(I_{0.3} / I_{1}+1\right) / 2$ (Bloemendal et al., 1992). Samples were taken following an adaptive strategy every $10 \mathrm{~cm}, 5 \mathrm{~cm}$ or $2 \mathrm{~cm}$ depending on the measured magnetic changes in the cores. S-ratio measurements help to characterize the relative contribution of low and high coercivity minerals. To complete the magnetic characterization, hysteresis parameters were determined using a Micromag 3900 vibrating sample magnetometer at the IPGP for samples from the same depths as the Sratio samples from core Klg07. Hysteresis measurements are used to characterize the magnetic grain size variations and the relative mineralogy of the sediments. Finally, scanning electronic microscopy (SEM) observations were made on selected prepared samples from Klg07 from which the argillaceous phases were removed. Data were obtained with a field emission SEM (FE-SEM Zeiss Sigma equipped with an EDS detector X-Max from Oxford Instruments) at ENS-Paris.

\section{Results}

\subsection{Variations of TOC, $\delta^{13} \mathrm{C}$ and $\mathrm{C} / \mathrm{N}$}

TOC values for Klg07, Klg06, Klg04 and Klg03 range from 0.6\% to $2.8 \%$ and generally increased down-core trend (Figs. 2; 3 and 4). In Klg07, TOC values are greater than $2 \%$ in the $300-320 \mathrm{~cm}$ interval (Fig. 2); this layer can thus be regarded as a sapropel. Above the sapropel, TOC values remain nearly constant at around $1.5 \%$, except for the first meter in which values are close to $1 \%$. In Klg06, maximum TOC values (2\%) are found at the base of the core at $360 \mathrm{~cm}$ (Fig. 3). From the core top to $100 \mathrm{~cm}$, TOC values are around $0.6 \%$, and increase to about $1 \%$ at $130 \mathrm{~cm}$. In Klg04, TOC values are higher than $2 \%$ from $360 \mathrm{~cm}$ to the core bottom (Fig. 4), which defines a sapropel layer. From the core top to $130 \mathrm{~cm}$, the mean value is about $0.7 \%$. At $160 \mathrm{~cm}$, TOC increases to a peak of $1.7 \%$. Below this interval values fluctuate between $1.4 \%$ and $1.1 \%$ to $360 \mathrm{~cm}$ (Fig. 4). Core Klg03 has TOC values of around $1 \%$ from the core top to $250 \mathrm{~cm}$ and increases to $1.5 \%$ in the $250 \mathrm{~cm}$ to $350 \mathrm{~cm}$ interval. In all the cores, $\mathrm{C} / \mathrm{N}$ ratio variations are similar to TOC variations. There is an overall increase down-core: from 8 to 13 in $\mathrm{Klg} 07$, from 6 to 10 in Klg06, from 6.5 to 11 in Klg04 and from 6.5 to 8.5 in Klg03. Ratios reach the highest values in the organic-rich layers and decrease sharply where TOC drops. $\delta^{13} \mathrm{C}$ values in $\mathrm{Klg} 07$ and Klg04 have more positive values at the core top compared to near the core bottom, varying roughly from -24 to -27 . Klg04 has a singular more positive peak $(-22.4)$ at $160 \mathrm{~cm}$ in the organic-rich layer. In $\mathrm{Klg} 03$ and Klg06, values fluctuate gently around -24 and -23.5 , respectively. In Klg03, more positive values are observed in the organicrich interval from $250 \mathrm{~cm}$ to $350 \mathrm{~cm}$. In Klg06, more negative values occur at the bottom of the core.

\subsection{XRF analysis}

Positive $\mathrm{Br}$ anomalies occur in the $100-140 \mathrm{~cm}$ and $300-330 \mathrm{~cm}$ intervals in Klg07, between 120 and $205 \mathrm{~cm}$ in Klg06 (Figs. 2 and 3, gray areas), between 145 and $175 \mathrm{~cm}$ in $\mathrm{Klg} 04$ and in the 100-150 cm and 250-300 cm intervals in Klg03 (Fig. 4, gray areas). Overall, the weighted average $\mathrm{Br}$ variations correlates strongly with TOC measurements (Figs. 2; 3 and 4). Positive $\mathrm{Br}$ anomalies correspond either to the sapropel level identified by TOC measurements (for example, the anomaly in the lower part of Klg07) or to increased organic matter contents (for example, the anomaly at the top of Klg07). This supports a relationship between marine organic carbon and $\mathrm{Br}$ as suggested by Ziegler et al. (2008) and implies that $\mathrm{Br}$ can probably be used as a proxy for organic matter content in the Marmara Sea. The ease of $\mathrm{Br}$ data collection using XRF scanning allows higher resolution than TOC measurements and enables resolution of small-scale organic content variations.

Fe contents for core Klg07 (Fig. 5-A) are used to investigate possible Fe enrichment/depletion in relation to $\mathrm{Br}$ and TOC variations. Fe contents are low in the $100-150 \mathrm{~cm}$ interval where the $\mathrm{Br}$ positive anomaly occurs. A large Fe enrichment occurs in the sapropel, followed by an Fedepleted interval from $350 \mathrm{~cm}$ to $400 \mathrm{~cm}$. Below $370 \mathrm{~cm}$, data are not considered reliable due to an increase by a factor of 5 of carbonate content that is likely to dilute the Fe concentration. $\mathrm{Ca}$ /Ti ratios (Fig. A.1) are used to correlate the cores and to infer the synchronicity of geochemical and magnetic changes (see discussion below). 


\section{KLG07}

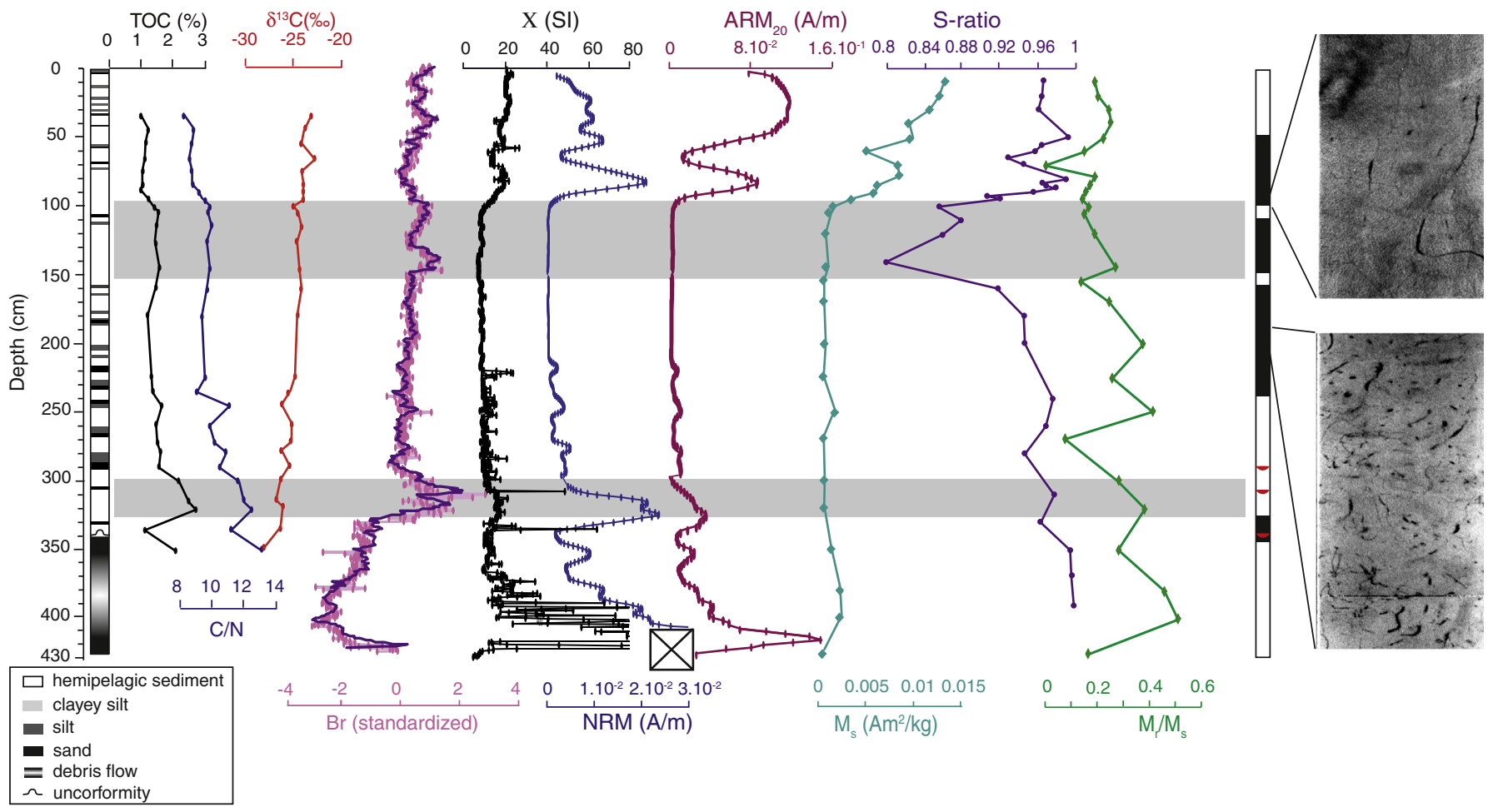

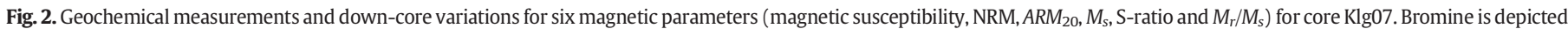

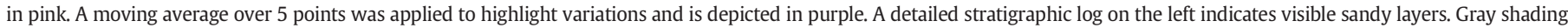

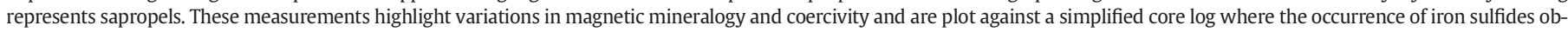
served with X-ray imaging is reported. (For interpretation of the references to color in this figure legend, the reader is referred to the web version of this article.)

\subsection{Magnetic record}

4.3.1. Magnetic susceptibility, NRM and $A R M_{20}$

Klg07 and Klg06 have similar magnetic properties with a remarkably sharp decrease in susceptibility, NRM and $A R M_{20}$ at $135 \mathrm{~cm}$ in
Klg06 and at $90 \mathrm{~cm}$ in Klg07 (Figs. 2 and 3). Susceptibility values drop by a factor of 3 to 2, respectively, in Klg06 and Klg07, while NRM values decrease abruptly by two orders of magnitude from a range of 0.5 $1.5 \times 10^{-2} \mathrm{~A} / \mathrm{m}$ to $10^{-4} \mathrm{~A} / \mathrm{m}$. The $A R M_{20}$ follows the same trend with values diminishing from $10^{-1} \mathrm{~A} / \mathrm{m}$ to nearly no measurable signal.

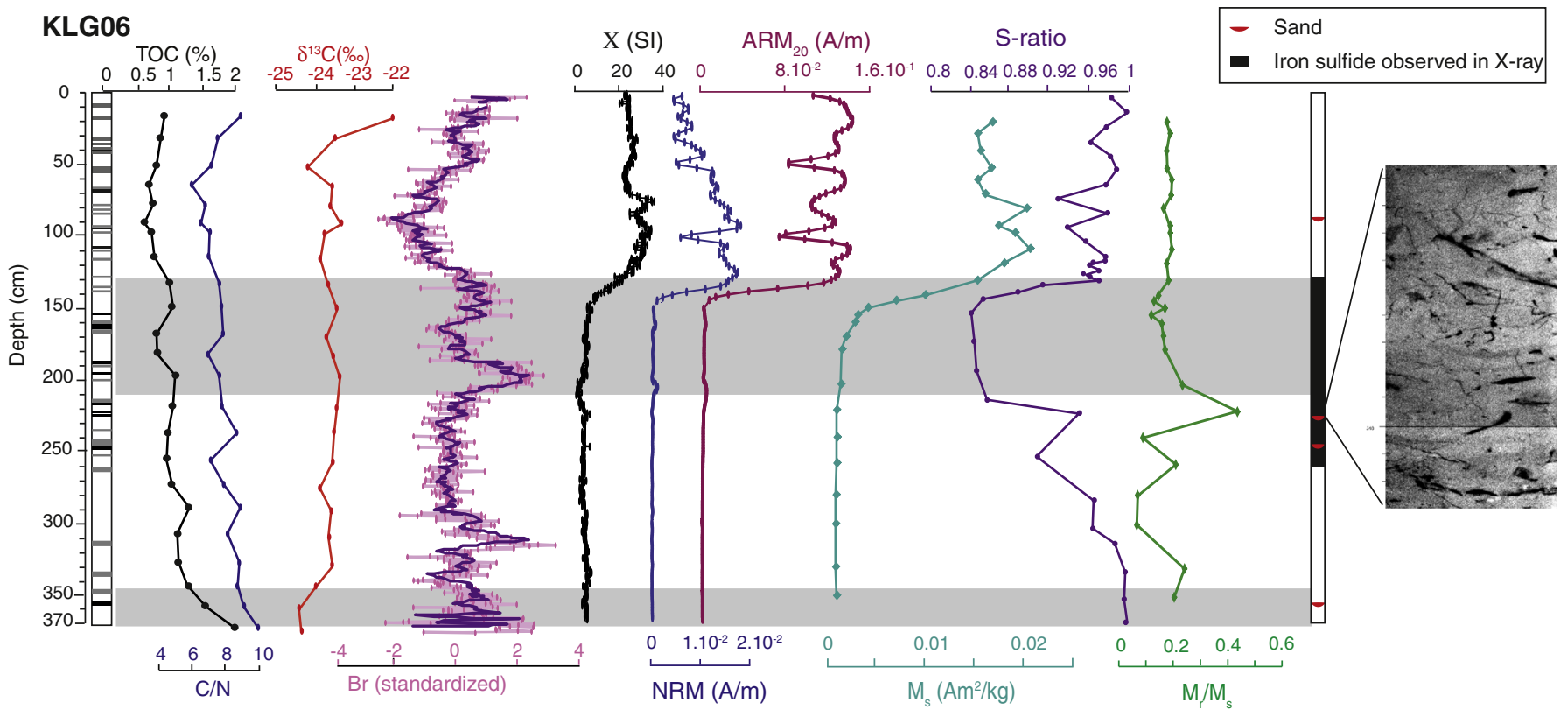

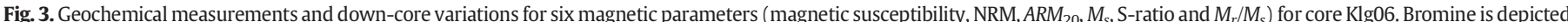

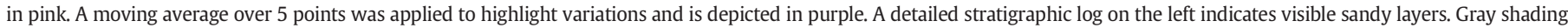

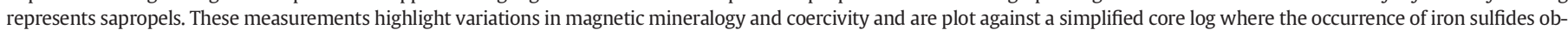
served with X-ray imaging is reported. (For interpretation of the references to color in this figure legend, the reader is referred to the web version of this article.) 


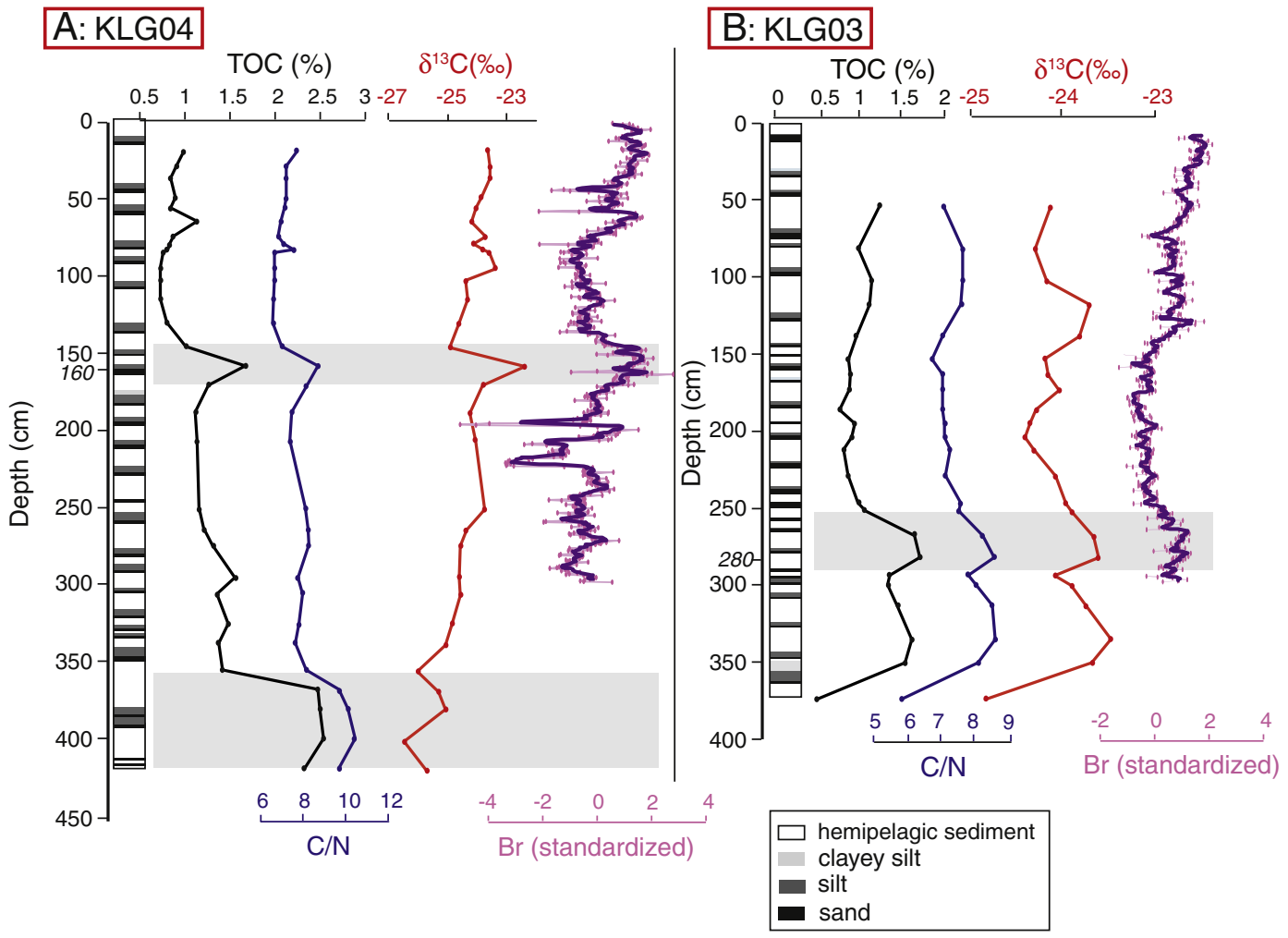

Fig. 4. Geochemical measurements for cores $\mathrm{Klg} 04$ (A) and $\mathrm{Klg} 03$ (B). See Fig. 2 caption explanations. Br was not measured for technical reasons at the bottom of the cores.

In both cores, these major magnetic properties changes occur across a stratigraphic interval less than $10 \mathrm{~cm}$ in thickness. Below this magnetic drop, $A R M_{20}$, NRM and magnetic susceptibility remain low to the base of the core in Klg06 and $220 \mathrm{~cm}$ in Klg07. From $220 \mathrm{~cm}$ to $305 \mathrm{~cm}$ in $\mathrm{Klg} 07$, magnetic susceptibility, NRM and $A R M_{20}$ increase again with some fluctuations. Below $330 \mathrm{~cm}$, NRM intensity and magnetic susceptibility reach the highest values measured in the core.

\subsubsection{Paleomagnetic results}

Only results from the top of the cores Klg06 and Klg07, where the NRM is of the order of $10^{-2} \mathrm{~A} / \mathrm{m}$ are discussed. This corresponds to the interval above $135 \mathrm{~cm}$ for Klg06 and above $90 \mathrm{~cm}$ for Klg07. For most samples, AF demagnetization diagrams (Zijderveld, 1967) reveal a soft viscous component, which is removed between 5 and $20 \mathrm{mT}$, to leave a linear trajectory toward the origin of the plot until the last demagnetization step at $70 \mathrm{mT}$ or $90 \mathrm{mT}$ (Fig. 6). The last demagnetization step corresponds to a decrease of $90 \%$ to $95 \%$ of the NRM. The straightforward demagnetization diagrams clear out identification of a ChRM component. As cores are not azimuthally oriented, only the ChRM inclination is reported in Fig. 6. The mean value is $38^{\circ}$ for Klg06 and $58^{\circ}$ for Klg07.

\subsection{Magnetic mineralogy and granulometry}

\subsubsection{SEM observations and X-ray imagery}

In X-ray images, elongated veins with sub-millimeter diameter and centimeter scale lengths appear from $80 \mathrm{~cm}$ in Klg06 (Fig. 3) to $50 \mathrm{~cm}$ in $\mathrm{Klg} 07$ (Fig. 2). Patches are also observed below $130 \mathrm{~cm}$ in Klg06 and $110 \mathrm{~cm}$ in $\mathrm{Klg} 07$. Observed dark spots and elongated veins in the $\mathrm{X}$-ray images are interpreted as iron sulfides.

SEM observations allow identification of iron oxides, in particular in the upper part of the cores. There, iron oxides are present as individual detrital grains or embedded in silicates with titanium often associated (Fig. 7-A). Below $1 \mathrm{~m}$ in Klg07, iron oxides are only preserved within flakes of silicate or clay minerals. SEM observations confirm the presence of iron sulfides throughout the cores in different shapes (Fig. 7). The Fe/S ratio enables identification of the predominant iron sulfide phase as pyrite $\left(\mathrm{FeS}_{2}\right)$. Above $90 \mathrm{~cm}$ in $\mathrm{Klg} 07$, framboidal pyrite appears mostly in spherical shapes of 10 to $20 \mu \mathrm{m}$ in diameter in association with euhedral pyrite within foraminifer shells (Fig. 7-A). They occur as elongated aggregates up to $100 \mu \mathrm{m}$ in diameter and correspond to veins observed in the X-ray images (Figs. 2 and 3). Below $90 \mathrm{~cm}$, pyrite is present in larger proportions within and outside shells (Fig. 7-B, $-C)$. They form larger aggregates composed of framboids and singular or grouped euhedral crystals. In addition, large veins formed by compact assemblages of crystals and framboids are common (Fig. 7-B, -C). EDS-X analyses on some polished euhedral crystals have $\mathrm{Fe} / \mathrm{S}$ ratios on the order of 0.75 , which indicates the presence of another phase, likely greigite $\left(\mathrm{Fe}_{3} \mathrm{~S}_{4}\right)$ (Fig. 7-B).

\subsubsection{S-ratio}

S-ratio data can be separated into three successive stratigraphic intervals (Figs. 2 and 3). The first interval (from the core top to $135 \mathrm{~cm}$ in $\mathrm{Klg} 06$ and to $90 \mathrm{~cm}$ in $\mathrm{Klg} 07$ ) is characterized by a high S-ratio (0.94-1). The second interval, from 135 to $220 \mathrm{~cm}$ in Klg06 and from 90 to $170 \mathrm{~cm}$ in $\mathrm{Klg} 07$, has lower values $(0.80-0.88)$ and the last interval, from $220 \mathrm{~cm}$ in $\mathrm{Klg} 06$ and from $170 \mathrm{~cm}$ in $\mathrm{Klg} 07$ to the end of both cores, is characterized by a rise back to high values in the range of 0.94-1 (Figs. 2 and 3). The high S-ratio values suggest the dominance of a low coercivity mineral, the most likely being magnetite. Lower values in the ratio indicate that the relative content of higher coercivity minerals increases. The high coercivity mineral is likely to be hematite but could also be linked to other phases as single domain greigite (Roberts et al., 2011).

\subsubsection{Thermomagnetic curves}

$\kappa-\mathrm{T}$ curves are dominated by: 1 ) a weak and nearly constant signal until $280{ }^{\circ} \mathrm{C} ; 2$ ) an increase of the magnetic susceptibility between $280{ }^{\circ} \mathrm{C}$ and $450{ }^{\circ} \mathrm{C} ; 3$ ) a decrease until $580{ }^{\circ} \mathrm{C}$ of the Curie point of magnetite, and; 4 ) irreversible cooling curves and a final magnetization at 

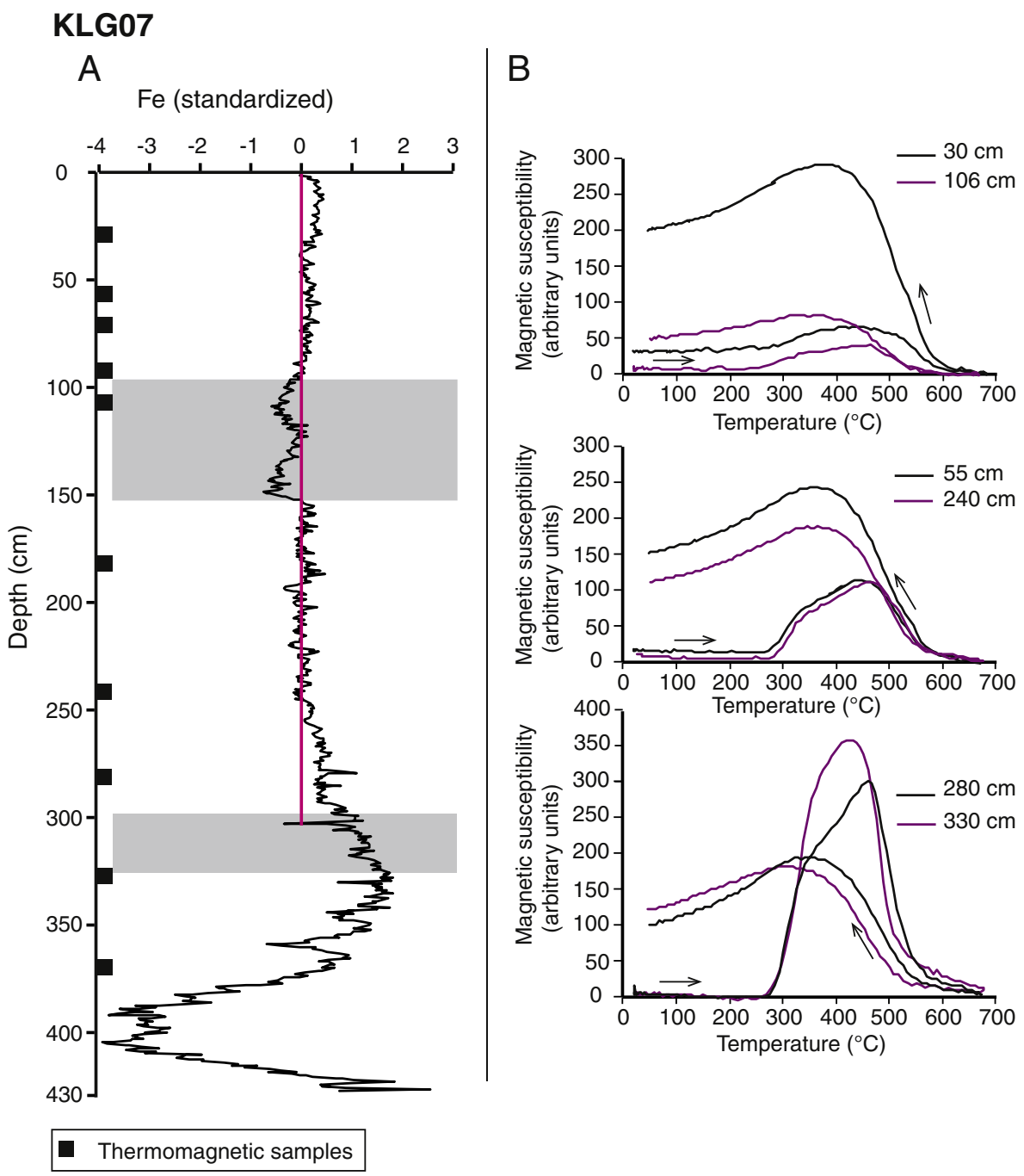

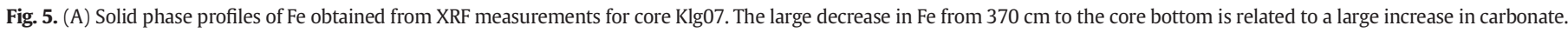
(B) Measurements of magnetic susceptibility vs. temperature. The position of the measured samples is indicated with black squares on (A).

least 10 times higher than the initial one (Fig. 5-B). The sharp magnetic susceptibility increase, starting in all samples at $280^{\circ} \mathrm{C}$, indicates the onset of a phase thermal alteration. This temperature is compatible with irreversible greigite decomposition upon heating (Dekkers et al., 2000; Roberts et al., 2011). High-temperature magnetic susceptibility variations undergo another inflection at $320{ }^{\circ} \mathrm{C}$ and a maximum at $450{ }^{\circ} \mathrm{C}$ (Fig. 5-B). This behavior is likely to correspond to the oxidation of pyrite to magnetite (Passier et al., 2001; Liu et al., 2004). The intensity of the peak between $280{ }^{\circ} \mathrm{C}$ and $580{ }^{\circ} \mathrm{C}$ generally increases down-core (Fig. 5-B).

Complementary information is provided by thermal demagnetization of the IRM, which indicates a down-core evolution in the nature of the mineral phase that carry the magnetization (Fig. 8). For the upper part of the core and above the magnetization drop (Fig. 8-A), we observe convex shapes with three successive unblocking temperatures: $250-300^{\circ} \mathrm{C}, 570-590^{\circ} \mathrm{C}$ and $\sim 650^{\circ} \mathrm{C}$. The demagnetization curves correspond to an assemblage of (by order of importance): 1) magnetite (with an unblocking temperature around $580^{\circ} \mathrm{C}$ ), which is the dominant magnetization carrier; 2) probable greigite (based on SEM results and on the destabilization observed in the $280^{\circ} \mathrm{C}$ range (Roberts et al., 2011)) and; 3 ) a small fraction of hematite possibly with minor substitution (with an unblocking temperature around $650{ }^{\circ} \mathrm{C}$ ). Just below the magnetic drop (at $120 \mathrm{~cm}$ and $140 \mathrm{~cm}$; see Fig. 8-B), the IRM intensity is one order of magnitude lower and hematite is the major magnetic phase, which is clearly identified by an unblocking temperature between $650{ }^{\circ} \mathrm{C}$ and $680{ }^{\circ} \mathrm{C}$. Deeper in the core (Fig. 8-C; -D), the signal is dominated by a phase with an unblocking (or destabilization) temperature of around $200-250^{\circ} \mathrm{C}$, possibly corresponding to an iron sulfid. A

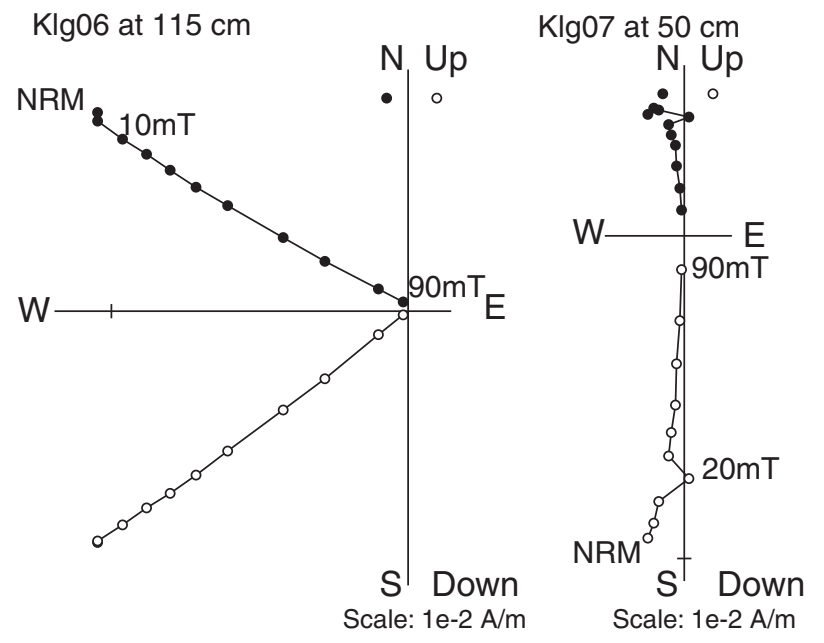

Fig. 6. Zijderveld (1967) diagram of demagnetization data for core Klg06 at $115 \mathrm{~cm}$ on the left and $\mathrm{Klg} 07$ core at $50 \mathrm{~cm}$ on the right. The solid circles represent projections onto the horizontal plane and open circles represent projections onto the vertical plane. 

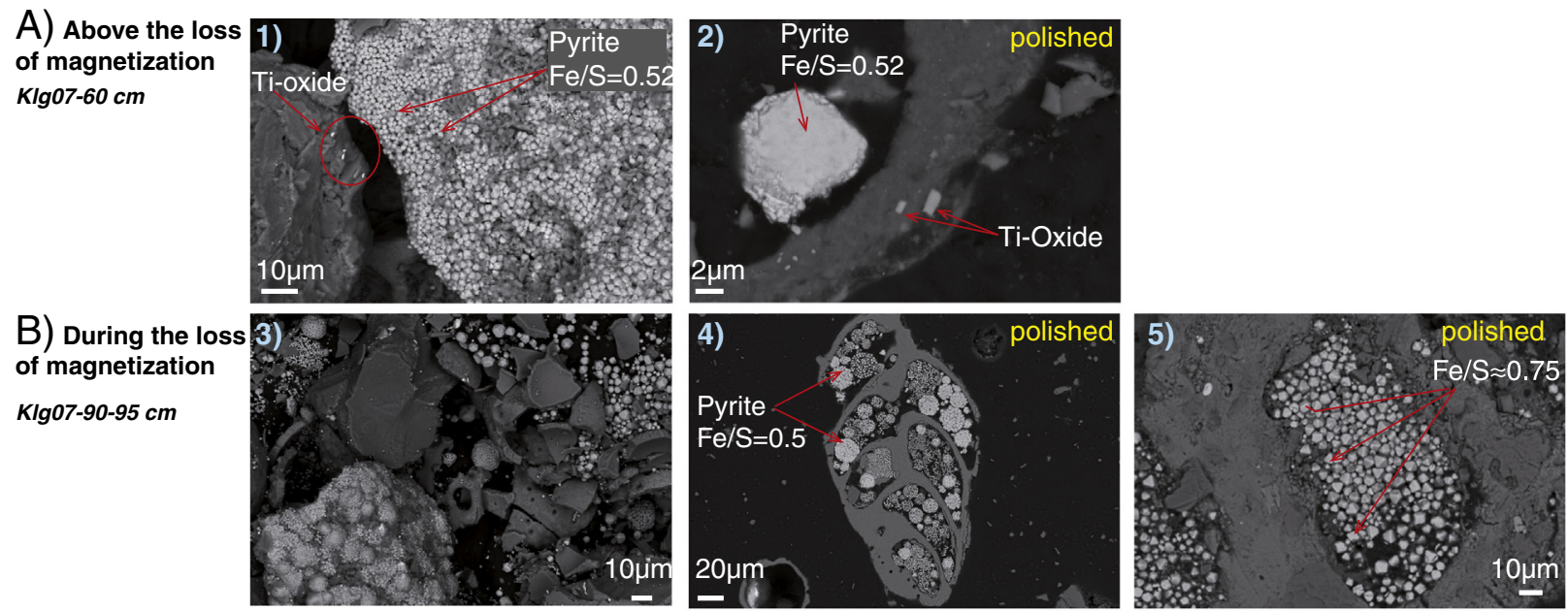

\section{C) Below the loss 6 of magnetization}

$K l g 07-212 \mathrm{~cm}$
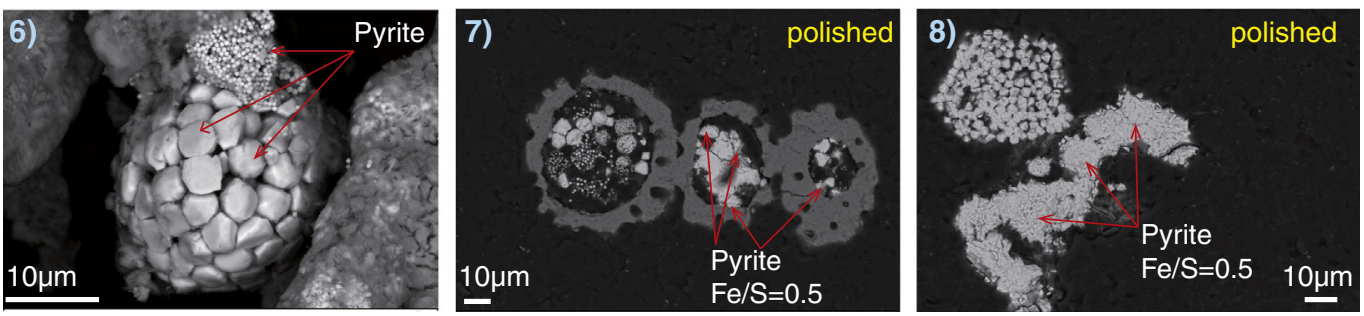

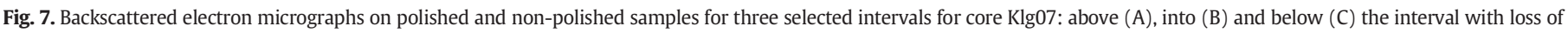

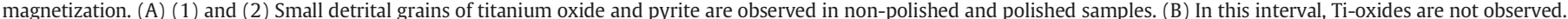

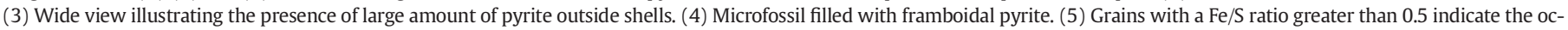

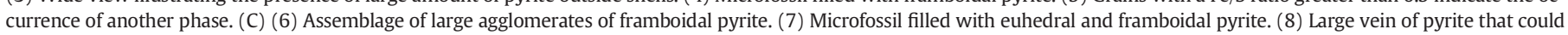
correspond to iron sulfides observed with X-ray imaging.
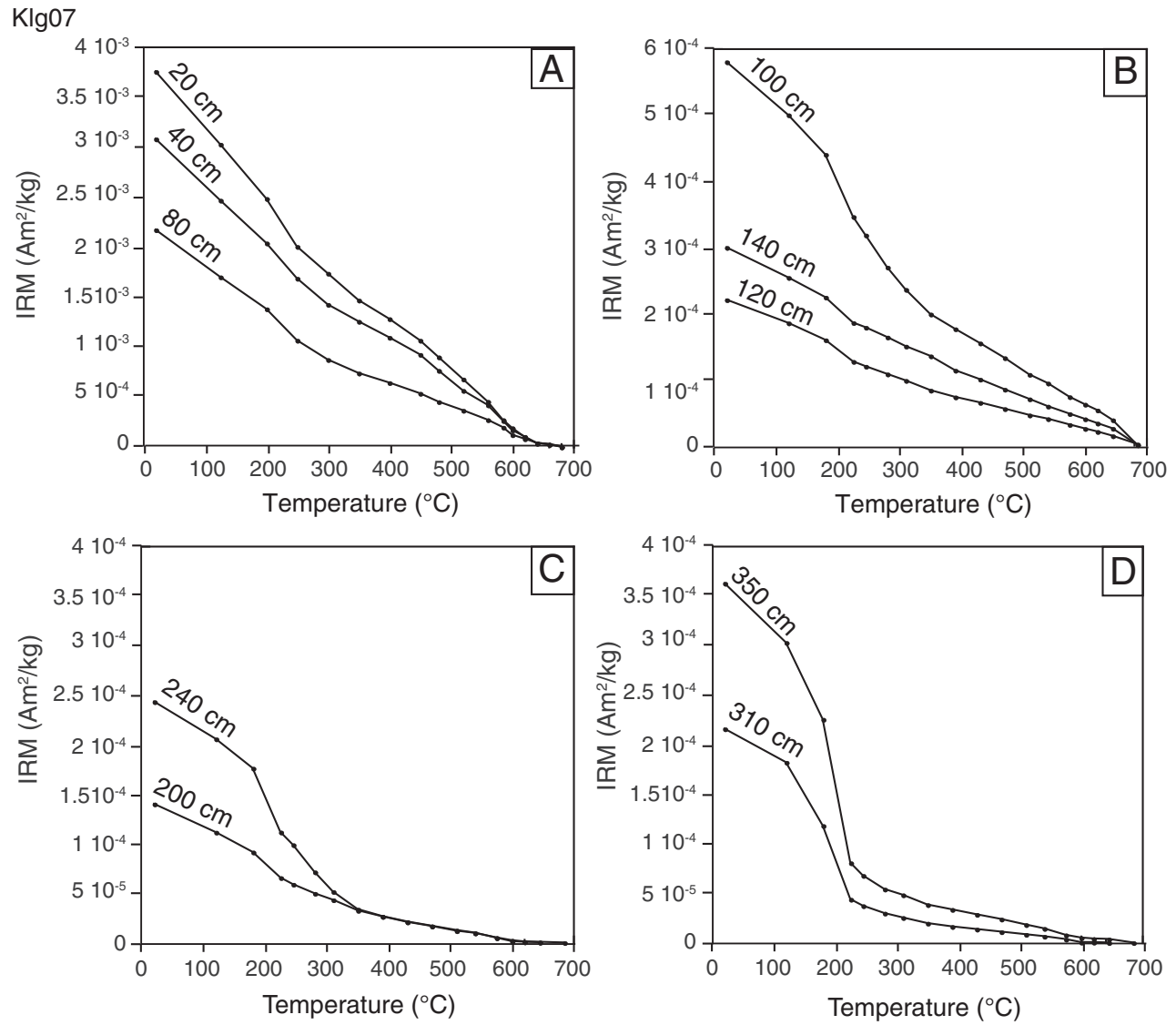

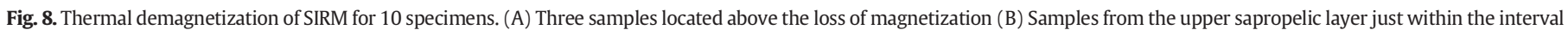
with loss of magnetization. (C) Two samples from below the upper sapropelic layer at 200 and $240 \mathrm{~cm}$. (D) Two samples from below the sapropel level at 300 and $350 \mathrm{~cm}$. 
faint signal due to magnetite remains and a small hematite fraction is present in the deepest sample (at $350 \mathrm{~cm}$ ).

\subsubsection{Hysteresis}

The saturation magnetization $\left(M_{S}\right)$ and the ratio of the saturation remanent magnetization $\left(M_{r}\right)$ to $M_{S}$ are represented for core Klg07 and Klg06 in Figs. 2 and 3, respectively. Above the magnetization drop, we observe in $\mathrm{Klg} 07$ a decrease in $M_{s}$ that reflects a decreased magnetite content. The picture is slightly different in $\mathrm{Klg} 06$, which has a higher $M_{s}$, which probably reflects a higher magnetite content (Fig. 3). The data highlight that during the magnetic drop, the two cores undergo a sharp decrease in magnetite content, as seen in $M_{s}$, and a relative decrease in the $M_{r} / M_{s}$ ratio (Figs. 2 and 3). The two parameters likely indicate dissolution of fine-grained ferrimagnetic grains of magnetite as observed by Channell and Hawthorne (1990) in the Tyrrhenian Sea. Below the magnetic drop, $M_{s}$ variations indicate that there is probably little magnetite left.

\section{Discussion}

\subsection{Records of paleosecular variation, age model and core correlation}

Mineralogical changes caused by diagenesis and stratigraphic modifications linked to earthquake shaking (Drab et al., 2012) suggest that a reliable paleomagnetic recording is far from being certain in the Marmara Sea. Attempts to recover a reliable paleomagnetic direction could only be made on the less magnetically degraded upper part of the cores, above the drop in magnetization where magnetite is identified as the dominant carrier and is likely to carry a detrital remanent magnetization (DRM). Nevertheless, a chemical remanent magnetization (CRM) could be superimposed on the DRM. Core Klg06 (Fig. 9) has inclination values that are shallower by $20^{\circ}$ compared to the inclination produced by a geocentric axial dipole (GAD) field $\left(60^{\circ}\right)$ at the site latitude $\left(40.8^{\circ} \mathrm{N}\right)$. The recording bias could have several causes, the most likely being superposition of the DRM by a CRM that caused coercivity overlap. Other mechanisms could be inclination shallowing (Tauxe and Kent, 1984) or tectonic disturbance in this seismically active area. More surprising is the apparently good preservation of the magnetic record in the upper part of Klg07 (Fig. 9), where, the mean inclination $\left(58^{\circ}\right)$ is close to the expected GAD value. Less substantial secondary mineral formation might have allowed better signal preservation. Another factor could be that bioturbation observed in Klg07 (Fig. 9) reduced constraints on grain movements thereby allowing more reliable paleomagnetic recording (Tucker, 1980).

We compare each of our records with the calculated inclination variation for the last 2000 years using the time varying spherical harmonic model CALS3K.4 of Korte and Constable (2011) and with a local curve obtained in the Balkans (Tema and Kondopoulou, 2011) (Fig. 7). Not surprisingly, the recorded variations in Klg06 are far from the expected variations. In contrast, core Klg07 records variations that are comparable with the standard curve (Fig. 9). Four points can be tied to recognizable inclination variations between $\mathrm{Klg} 07$ and the two models. Uncertainties in this correlation occur due to the unknown locking delay of the magnetic signal (acquisition of the magnetic record postdates sediment deposition, and hence shifts the record to younger age) and to lack of accuracy of the reference curve. An arbitrary uncertainty of \pm 200 years is thus added to the results following estimates by Ledu et al. (2010). These points are used in addition to radiocarbon ages from planktonic foraminifera and mollusk shells to compare the age model derived from secular variation with other dating techniques and to establish a more detailed age model for Klg07 (Fig. 10). Using linear correlation, a mean sedimentation rate of $37 \mathrm{~cm} / \mathrm{kyr}$ is found using all available age data (Fig. 10). If we restrict the data set to radiocarbon ages we obtain an average rate of $38 \mathrm{~cm} / \mathrm{kyr}$. This indicates that the age model developed using paleomagnetic inclination variations form core $\mathrm{Klg} 07$ is fully compatible with isotopic ages.

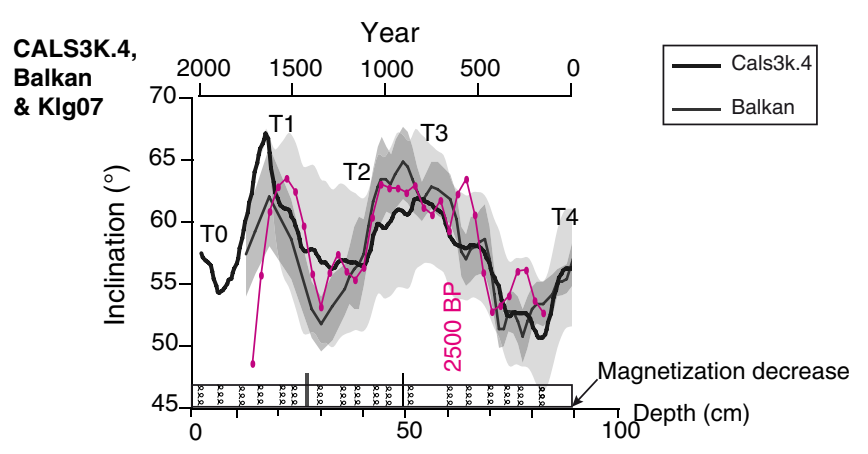

KLG06
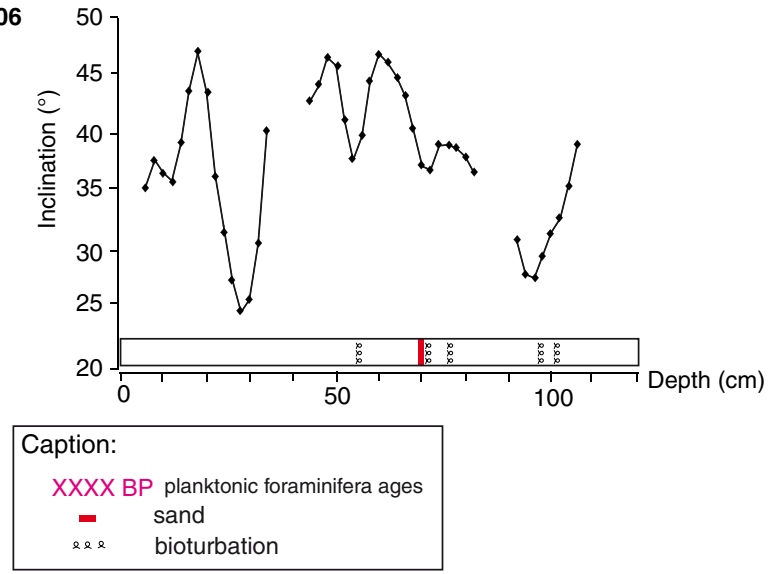

Fig. 9. Cals3k.4 geomagnetic field and Balkan models (on top) with associated error bars and paleo-inclination record for the first $90 \mathrm{~cm}$ of core Klg07 and $120 \mathrm{~cm}$ of core Klg06. The model results have trends with periods of low and high inclinations. The same trends are observed for Klg07 (superposed curve on the two model curves) but not for Klg06 (below). The core logs present areas where bioturbation is observed. Radiocarbon age for the cores is indicated on the core log.

No reliable correlation with the inclination reference curve can be made for Klg06. Nevertheless, Klg06 and Klg07 can be matched using Ca/Ti XRF data (Fig. A.1, Drab et al. (2012)). The correlation implies that the drop in magnetization at $150 \mathrm{~cm}$ for Klg06 is synchronous with the drop at $90 \mathrm{~cm}$ for Klg07. An age model can thus be inferred for Klg06 using the five tie points between the two cores (Fig. A.1). Using a linear correlation a mean sedimentation rate of $52 \mathrm{~cm} / \mathrm{kyr}$ is determined for core Klg06 (Fig. 10).

\subsection{Characteristics of Marmara Sea sapropel and sapropel dating}

\subsubsection{Upper sapropelic layer}

The down-core increase of organic matter and $\mathrm{C} / \mathrm{N}$ ratio occurs in cores Klg07, Klg06, Klg04 and Klg03 at, respectively, $100 \mathrm{~cm}, 130 \mathrm{~cm}$, $150 \mathrm{~cm}$ and $250 \mathrm{~cm}$ (Figs. 2, 3 and 4). In our age model (see also Drab et al. (2012)), this sudden OM increase is likely synchronous and occurred about 2500 years ago. This age corresponds roughly to the age of the top of the upper sapropelic level in the Marmara Sea, which was dated at 3200 to 2500 years by Tolun et al. (2002). The increased $\mathrm{OM}$ is associated with $\mathrm{Br}$-enriched intervals, between 100 and $140 \mathrm{~cm}$ in Klg07, between 120 and $205 \mathrm{~cm}$ in Klg06 and between 145 and $175 \mathrm{~cm}$ in $\mathrm{Klg} 04$.

The moderate TOC enrichment for the upper sapropelic layer in the studied cores (with values below $2 \%$ ) may be due to degradation and poor preservation of the OM during diagenesis.

$\mathrm{C} / \mathrm{N}$ and $\delta^{13} \mathrm{C}$ measurements provide information about the origin of the upper sapropelic layer. Increased organic carbon could indicate: 1) enhanced marine productivity; 2) increased terrestrial organic matter; and/or 3) better OM preservation. The upper sapropelic layer is 

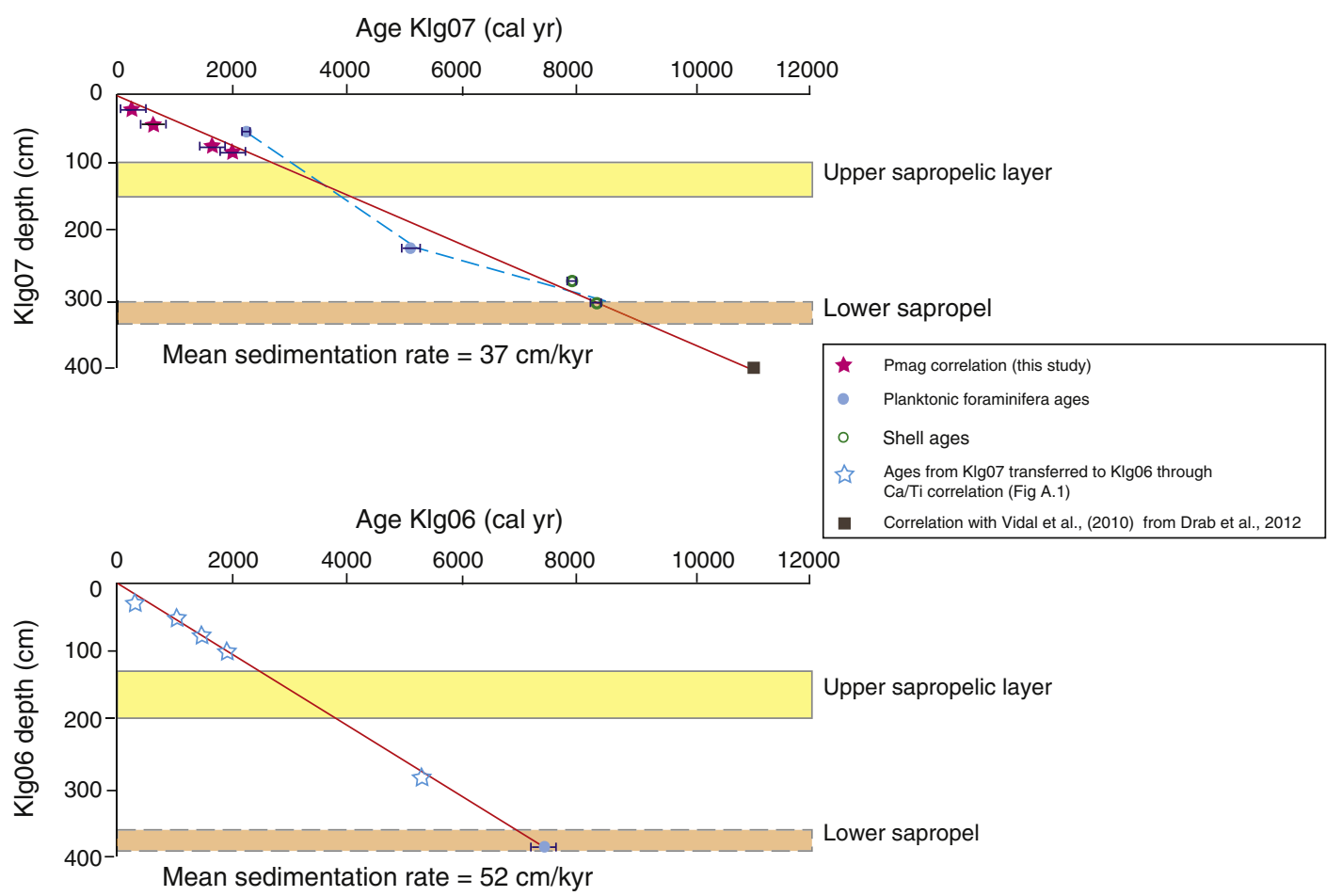

Fig. 10. Age models for cores Klg07 (top) and Klg06 (bottom). The tie points for Klg06 (open stars) are from Ca/Ti correlation of cores Klg07 and Klg06.

associated with slightly higher $\mathrm{C} / \mathrm{N}$ ratios, which can be interpreted as due to a higher input of terrestrial OM (Likens et al., 1981; Meyers, 1994; Briggs et al., 2013). The association of high organic carbon and high C/N ratios was also observed by Tolun et al. (2002) in the Marmara Sea. However, this interpretation should be regarded with caution as C/ $\mathrm{N}$ values can also be affected by anaerobic degradation of organic matter, resulting in higher $\mathrm{C} / \mathrm{N}$ ratios by preferential removal of $\mathrm{N}$ (Meyers, 1994; Briggs et al., 2013). $\delta^{13} C$ variations often used as a marker for marine vs terrestrial origin do not change significantly in Klg06 and Klg07. The same observation holds for most $\delta^{13} \mathrm{C}$ records from the Marmara Sea (Fig. 11). However in the Cinarcık Basin, Klg03 and Klg04 cores show $\delta^{13} \mathrm{C}$ values that clearly increase to more positive values (Fig. 11), which could indicate an increase in the proportion of marine-derived OM (Gearing et al., 1977). An increase in the planktonic foraminifer G. Ruber is also documented by Sperling et al. (2003) at this age. Both data, thus, indicate enhanced surface water productivity.

\subsubsection{Lower sapropel}

Based on TOC measurements, a second sapropel level is identified in the 300-320 cm interval in Klg07, at the bottom of Klg06 (i.e. $360 \mathrm{~cm}$ ) and between 360 and $420 \mathrm{~cm}$ in Klg04. According to the Ca/Ti correlation, this second sapropel seems synchronous in all three cores (Fig. A.1). Following our age model for Klg07 the termination of the sapropel deposition was at around 8 kyr BP (Fig. 10). Comparison with other dated records in the Marmara Sea (Fig. 11; Aksu et al. (2002); Tolun et al. (2002); Sperling et al. (2003)) suggests that this organic-rich level corresponds to the $\mathrm{S} 1$ Marmara/M1 lower sapropel. Our results, thus, confirm the presence of the $\mathrm{S} 1$ episode in the Marmara
Sea. This level is characterized in our study by $\mathrm{C} / \mathrm{N}$ values above 10 , which likely indicates preserved marine OM. Based on biomarkers, Sperling et al. (2003) and Vidal et al. (2010) suggested that the deposition of the lower sapropel is correlates with a global transgression and associated enhanced primary productivity sustained by reorganization of the phytoplankton community.

\subsection{Magnetic properties of sapropels and their environmental significance}

Magnetization drops are often observed in sediments (e.g. Florindo et al., 2003), but sharp decreases of two orders of magnitude over stratigraphic intervals of few centimeters, as observed in cores Klg06 and Klg07 at $135 \mathrm{~cm}$ and $90 \mathrm{~cm}$, respectively, need to be explained. This indicates a strong and localized dissolution of the dominant magnetic carriers triggered by intense microbial sulfate reduction at a level that combines abundant, easily degradable organic carbon and large surface area/volume reactive iron oxide phases. Recent studies on sapropels have shown that rich and active bacterial populations can be fueled for as long as several thousand years by high OM within these layers (Süß, 2007). The bottom of the layer is not defined by a return to high magnetic values. This indicates a downward migration of sulfide that caused dissolution of magnetic minerals well below the upper sapropelic layer. The presence of a downward sulfidization front has been observed in sapropel-bearing sediments (Passier et al., 1996; Larrasoaña et al., 2003). In addition, an oxidation front diffusing from the immediate layer overlying the sapropel after completion of sapropel formation has been described as a common characteristic of Eastern Mediterranean sapropels (De Lange et al., 1989; Van Santvoort

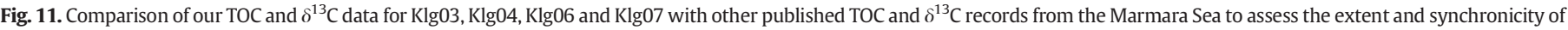

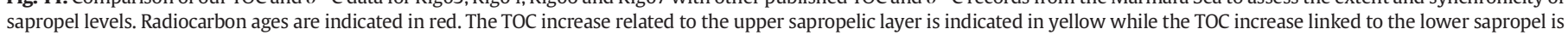
depicted in orange. (For interpretation of the references to color in this figure legend, the reader is referred to the web version of this article.) 


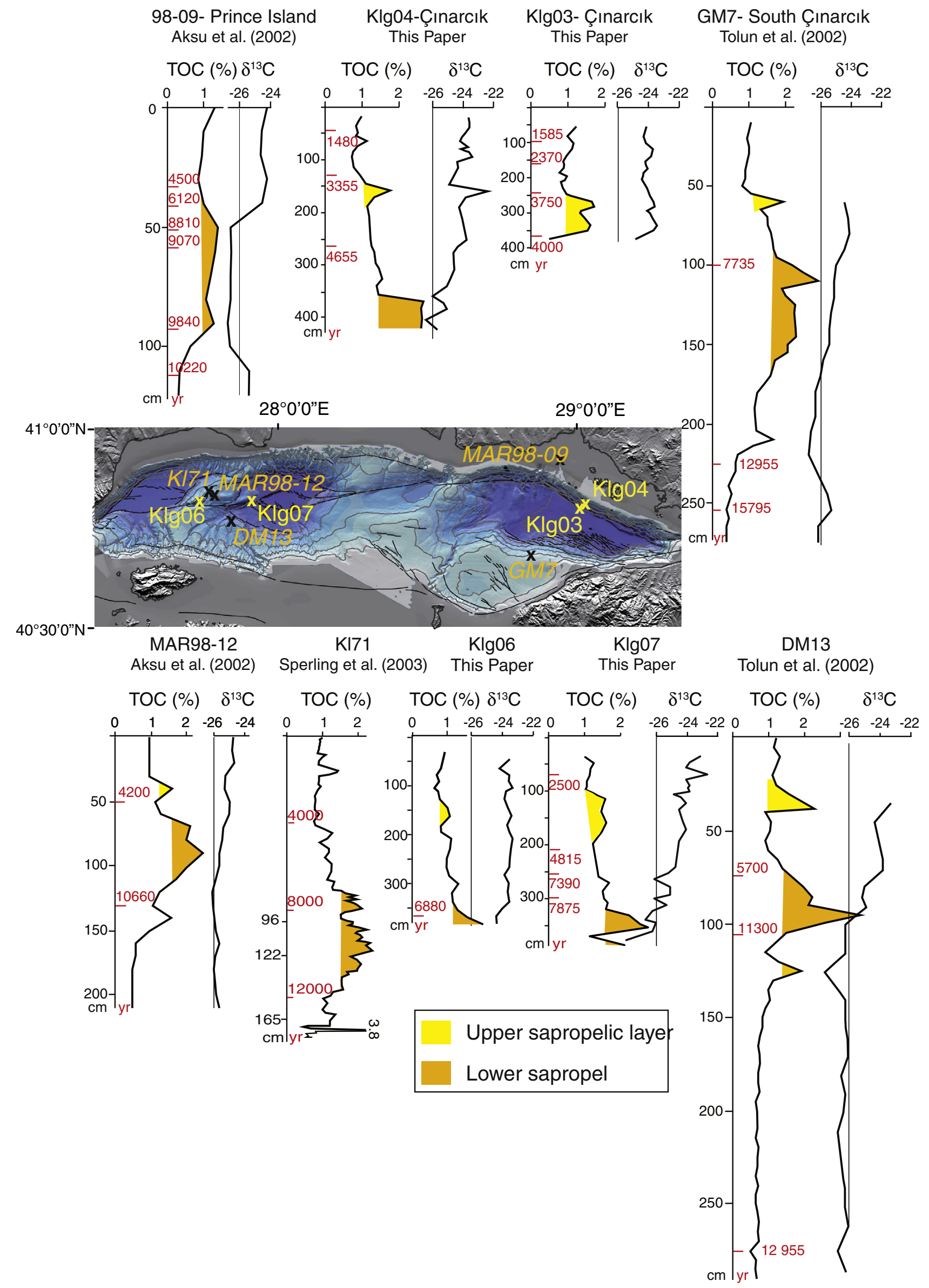


et al., 1997; Thomson et al., 1999; Passier et al., 2001; Larrasoaña et al., 2003). This oxidation front captures any liberated ferrous iron and gives rise to formation of fine-grained magnetite that adds to the magnetic detrital particles from the background sediment. The presence of a reductive dissolution front and an oxidation front that act as competing mechanisms at the centimeter scale accounts well for the sharp transition observed just above the upper sapropelic layer.

In contrast, other magnetic parameters such as the S-ratio indicate that the upper sapropelic layer is associated with the presence of a high coercivity phase. Based on thermal demagnetization of the SIRM, hematite is identified as a major remanence carrier within the upper sapropelic layer. The presence of resistant hematite in sulfidic environment has already been observed in several studies (Yamazaki et al., 2003; Liu et al., 2004; Garming et al., 2005; Rey et al., 2005). This result is in agreement with recent measurements on the reactivity of iron oxides toward dissolved sulfide (Poulton et al., 2004) showing that hematite is 2 to 3 times more resistant to dissolution than magnetite. An alternative possibility would be that hematite forms after pyrite if the dissolved oxygen concentration rises in interstitial waters (Berner, 1981). This could be triggered by a re-oxygenation episode after the sapropel deposition

Despite the moderate TOC contents in the upper parts of Klg06 and Klg07, magnetic properties confirm the occurrence of an upper sapropelic episode as first suggested by Çağatay et al. (1999) and discussed by Tolun et al. (2002). In addition, magnetic property variations at the onset and termination of the sapropel interval have implications for evolution of bottom water ventilation. The upper sapropelic layer was probably triggered by a combination of accumulation of $\mathrm{OM}$ associated with an episode of low bottom water ventilation caused by variations in the path of dense saline Mediterranean waters over several hundred years. The presence of hematite, if not post-depositional, indicates that the dissolution of iron oxide phases is not complete; the exposure to dissolved sulfide was thus high enough (or lasted long enough) to dissolve magnetite but not hematite. This event was followed by oxic or suboxic conditions with moderate re-ventilation of bottom waters, which did not allow reformation of significant magnetite at the top of the sapropel interval.

The lower sapropel is well characterized in the studied cores by TOC values $>2 \%$ and high NRM and ARM remanences in core Klg07. This sapropel is therefore not characterized by a dissolution front as in the upper sapropelic layer but instead has a relative magnetic enhancement. The magnetic signal associated with the lower sapropel thus contrasts sharply with the upper sapropelic layer. Similar behavior has been described by Roberts et al. (1999) and Reinholdsson et al. (2013) who noted a correlation between the degree of magnetic enhancement and the organic carbon content in sapropels, with high organic carbon corresponding to high concentrations of magnetic minerals. Reinholdsson et al. (2013) associated this behavior to the activity of MTB population and production of greigite magnetosomes. Larrasoaña et al. (2003) proposed a different scenario involving: 1 ) less intense sulfate reduction within this type of sapropel with enhanced magnetization; 2) no or moderate downward dissolution front; and 3) post-depositional oxidation with reformation of fine-grained magnetite. The high NRM, susceptibility and $\mathrm{Mr} / \mathrm{Ms}$ measured within the lower sapropel indeed suggest a population of fine-grained magnetite although ultra-fine greigite could not be totally rejected. The enhanced magnetization could in our case be the mark of increased primary productivity and phytoplankton activity as shown by Vidal et al. (2010) and Sperling et al. (2003), as well as of moderate anoxia in bottom waters followed by active re-ventilation. Presumably, if fine magnetite grains are responsible for the high magnetic signal it does not require fully anoxic conditions. In any case, the reconnection with the Black Sea between 8 and 9 ka B.P. led to the outflow of freshwater and changes in circulation in the Marmara Sea that strongly influenced bottom water ventilation and appear to be responsible for the high magnetic signal in the lower sapropel.

Finally, it should be noted that unusually high methane flux are reported in the Marmara Sea (Çağatay et al., 2004; Tryon et al., 2012; Crémière et al., 2013). The North Anatolian Fault is associated with active fluid expulsion and development of an active hydrothermal system (Halbach et al., 2004; Armijo et al., 2005; Tryon et al., 2010). As a result, shallow redox reactions have been documented, and are enhanced by anaerobic methane oxidation at the sulfate-methane interface. In this particular setting the signature of sapropels can be altered more rapidly, as microbial degradation of organic matter fuels sulfate reduction. However, it is unlikely that a strong methane signal overprints the magnetic signal in our cores as the diagenesis is associated to well-defined horizons and not to patches along micro-fractures guiding methane flux. In addition, magnetic minerals associated with methane venting are reported in Larrasoaña et al. (2007), who described characteristic authigenic greigite and pyrrhotite, which were not observed in the studied cores.

\section{Conclusion}

The combined magnetic and chemical records obtained in this study enable recognition and characterization of the two most recent sapropel layers from the Marmara Sea. An upper sapropelic layer is recorded about 2500 years ago and is marked by a moderate increase in organic carbon and $\mathrm{Br}$. It is also synchronous with a strong reductive front that diffused downward and caused the dissolution of magnetite and formation of iron-sulfides. Moderate re-oxygenation of bottom waters just after the period of sapropel deposition marks the sharp termination of the sapropel layer. A lower sapropel is also recorded and is characterized by total organic carbon values greater than $2 \%$. This layer, dated around 8-9 ka BP, is particularly marked in core Klg07. Unlike the upper sapropelic layer, the lower sapropel has high NRM and susceptibility, which indicates a magnetic enhancement probably due to either incomplete reductive dissolution and a very active re-oxidation front (Larrasoaña et al., 2003) and/or to the presence of a highly magnetic non-sulfide mineral as observed by Stoner et al. (1998); Roberts et al. (1999) and Reinholdsson et al. (2013). We favor an interpretation where this is the hallmark of less anoxic conditions. Finally, $\mathrm{Br}$ can be considered a good proxy for TOC content in the Marmara Sea. XRF measurement of $\mathrm{Br}$ could, thus, be used as first means to recognize of levels with high carbon contents and may help to characterize sapropels in future studies.

\section{Acknowledgments}

We greatly thank Gert de Lange, Andrew P. Roberts and an anonymous reviewer for their thorough and very constructive revisions of the manuscript. Trevor Williams is thanked for critical reading of the paper. We thank Rolando Armijo who was the chief scientist of the Marmarascarps mission in 2002 during which studied cores were recovered. We are grateful to Isabelle Billy, Joel Saint-Paul and Olivier Ther for core sampling, X-ray scanner imaging and XRF data acquisition. Catherine Kissel allowed us to complete our paleomagnetic measurements when the magnetometer at the IPGP was not available. We are grateful to Damien Deldique who helped with SEM measurements and Jean-Pierre Valet for fruitful discussions. Radiocarbon dating was supported by the CNRS-INSU Artemis program and was done in the Artemis LMC14 laboratory with support from Crédit Chercheur du Fond National pour la Recherche Scientifique Belge under the project SEISMARM. The program CNRS/FRS-FNRS CGRI supported XRD data acquisition in Liège (Belgium), the ENS UMR8538 and IPGP UMR 7154 provided additional financial support for data acquisition. This is IPGP contribution \#3580. 


\section{Appendix A}

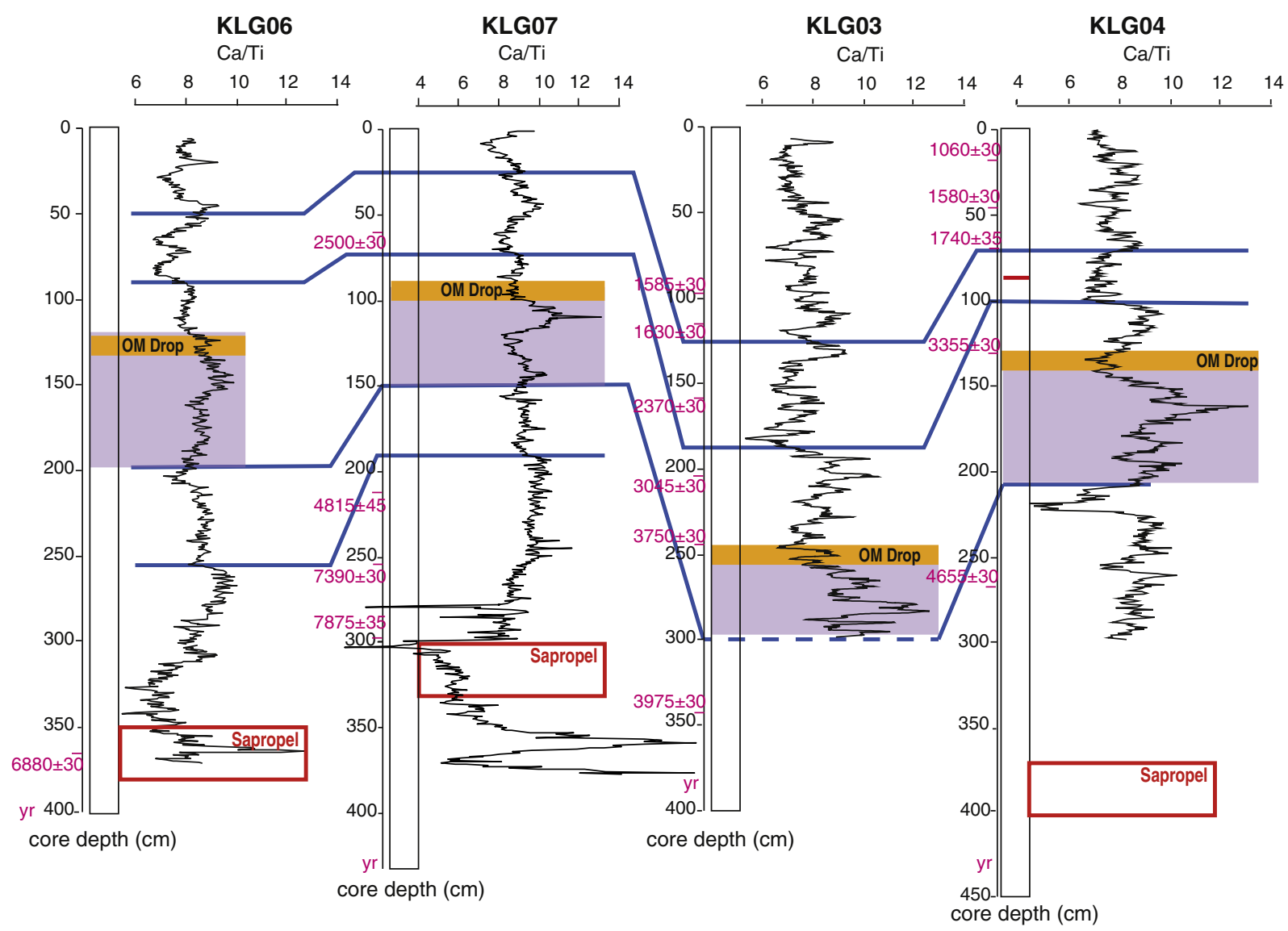

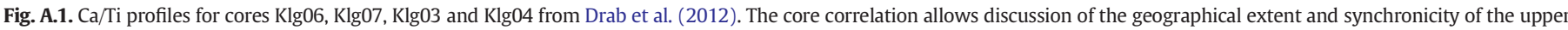

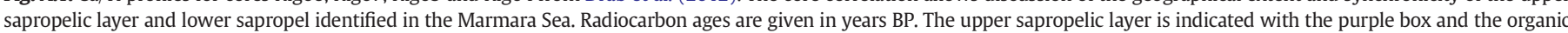

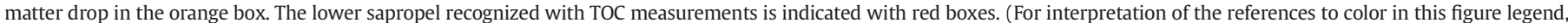
the reader is referred to the web version of this article.)

\section{References}

Aksu, A., Hiscott, R., Yasar, D., 1999. Oscillating Quaternary water levels of the Marmara Sea and vigorous outflow into the Aegean Sea from the Marmara Sea Black Sea drainage corridor. Mar. Geol. 153, 275-302.

Aksu, A., Hiscott, R., Mudi, P., Rochon, A., Kaminski, M., Abrajano, T., Yasar, D., 2002. Persistent Holocene outflow to the Eastern Mediterranean contradicts Noah's flood hypothesis. GSA Today 12, 4-10.

Armijo, R., Meyer, B., Hubert, A., Barka, A., 1999. Westward propagation of the North Anatolian fault into the northern Aegean: timing and kinematics. Geology 27, 267-270.

Armijo, R., Meyer, B., Navarro, S., King, G., Barka, A., 2002. Asymmetric slip partitioning in the Sea of Marmara pull-apart: a clue to propagation processes of the North Anatolian Fault? Terra Nova 14, 80-86.

Armijo, R., Pondard, N., Meyer, B., Uçarkus, G., de Lepinay, B., Malavieille, J., Dominguez, S., Gutscher, M., Schmidt, S., Beck, C., Çağatay, N., Çakr, Z., Imren, C., Eris, K., Natalin, B., Ozalaybey, S., Tolun, L., Lefevre, I., Seeber, L., Gasperini, L., Rangin, C., Emre, O., Sarikavak, K., 2005. Submarine fault scarps in the Sea of Marmara pull-apart (North Anatolian Fault): implications for seismic hazard in Istanbul. Geochem. Geophys. Geosyst. 6, 1-29.

Bahr, A. Lamy, F. Arz, H., Kuhlmann, H., Wefer, G, 2005. Late Glacial to Holocene climate and sedimentation history in the NW Black Sea. Mar. Geol. 214, 309-322.

Barka, A., Kadinsky-Cade, K., 1988. Strike-slip fault geometry in Turkey and its influence on earthquake activity. Tectonics 7, 663-684.

Beck, C., Mercier de Lépinay, B., Schneider, J.L., Cremer, M., Çağatay, N., Wendenbaum, E., Boutareaud, S., Ménot, G., Schmidt, S., Weber, O., Eris, K., Armijo, R., Meyer, B., Pondard, N., Gutscher, M.A., MARMACORE Cruise Party, Turon, J.-L., Labeyrie, L., Cortijo, E., Gallet, Y., Bouquerel, H., Gorur, N., Gervais, A., Castera, M.-H., Londeix, L, de Rességuier, A., Jaouen, A., 2007. Late Quaternary co-seismic sedimentation in the Sea of Marmara's deep basins. Sediment. Geol. 199, 65-89.

Berner, R.A., 1981. A new geochemical classification of sedimentary environments. J. Sediment. Res. 51, 0359-0365.
Besiktepe, C., Sur, H., Ozsoy, E., Latif, M., Oguz, T., Unluata, U., 1994. The circulation and hydrography of the Marmara Sea. Prog. Oceanogr. 34, 285-334.

Bloemendal, J., King, J.W., Hall, F., Doh, S., 1992. Rock magnetism of late Neogene and Pleistocene deep-sea sediments: relationship to sediment source, diagenetic processes, and sediment lithology. J. Geophys. Res. 97, 4361-4375.

Briggs, R., Ruttenberg, K., Glazer, B., Ricardo, A., 2013. Constraining sources of organic matter to tropical coastal sediments: consideration of nontraditional end-members. Aquat. Geochem. 19, 543-563.

Cağatay, M., Algan, O., Sakinç, M., Eastoe, M., Egesel, L., Balkis, N., Ongan, D., Caner, H. 1999. A mid-late Holocene sapropelic sediment unit from the southern Marmara Sea shelf and its palaeoceanographic significance. Quat. Sci. Rev. 18, 531-540.

Cağatay, M., Görür, N., Algan, O., Eastoe, C., Tchapalyga, A., Ongan, D., Kuhn, T., Kuscu, I, 2000. Late Glacial-Holocene palaeoceanography of the Sea of Marmara: timing of connections with the Mediterranean and the Black Seas. Mar. Geol. 167, 191-206.

Çăgatay, M., Görür, N., Polonia, A., Demirbağ, E., Sakinç, M., Cormier, M., Capotondi, L. McHugh, C., Emre, O., Eris, K., 2003. Sea-level changes and depositional environments in the Izmit Gulf, eastern Marmara Sea, during the Late Glacial-Holocene period. Mar. Geol. 202, 159-173.

Cağatay, M., Özcan, M., Güngör, E., 2004. Pore-water and sediment geochemistry in the Marmara Sea (Turkey): early diagenesis and diffusive fluxes. Geochem. Explor. Environ. Anal. 4, 213-225.

Campos, C., Beck, C., Crouzet, C., Demory, F., Van Welden, A., Eris, K., 2013. Deciphering hemipelagites from homogenites through anisotropy of magnetic susceptibility. Paleoseismic implications (Sea of Marmara and Gulf of Corinth). Sediment. Geol. 292, 1-14.

Canfield, D., Berner, R.A., 1987. Dissolution and pyritization of magnetite in anoxic marine sediments. Geochim. Cosmochim. Acta 51, 645-659.

Casford, J., Rohling, E., Abu-Zied, R., Fontanier, C., Jorissen, F., Leng, M., Schmiedl, G., Thomson, J., 2003. A dynamic concept for Eastern Mediterranean circulation and oxygenation during sapropel formation. Palaeogeogr. Palaeoclimatol. Palaeoecol. 190, 103-119. 
Channell, J.E.T., Hawthorne, T., 1990. Progressive dissolution of titanomagnetites at ODP Site 653 (Tyrrhenian Sea). Earth Planet. Sci. Lett. 96, 469-480.

Cowie, G., Hedges, J.I., 1994. Biochemical indicators of diagenetic alteration in natural organic matter mixtures. Nature 369, 304-307.

Cramp, A., O'Sullivan, G., 1999. Neogene sapropels in the Mediterranean: a review. Mar. Geol. 153 (1-4), 11-28.

Crémière, A., Bayon, G., Ponzevera, E., Pierre, C., 2013. Paleo-environmental controls on cold seep carbonate authigenesis in the Sea of Marmara. Earth Planet. Sci. Lett. 376, 200-211.

De Lange, G., Middelburg, J., Pruysers, P., 1989. Middle and late quaternary depositional sequences and cycles in the Eastern Mediterranean. Sedimentology 36, 151-156.

De Lange, G., Thomson, J., Reitz, A., Slomp, C., Principato, M., Erba, E., Corselli, C., 2008. Synchronous basin-wide formation and redox-controlled preservation of a Mediterranean sapropel. Nat. Geosci. 1, 606-610.

De Rijk, S., Hayes, A., Rohling, E.J., 1999. Eastern Mediterranean sapropel S1 interruption: an expression of the onset of climatic deterioration around 7 ka BP. Mar. Geol. 153, 337-343.

Dekkers, M.J., Passier, H., Schoonen, M., 2000. Magnetic properties of hydrothermally synthesized greigite $\left(\mathrm{Fe}_{3} \mathrm{~S}_{4}\right)$-II. High-and low-temperature characteristics. Geophys. J. Int. 141, 809-819.

Drab, L., Hubert, A., Schmidt, S., Martinez, P., 2012. The earthquake sedimentary record in the western part of the Sea of Marmara, Turkey. Nat. Hazards Earth Syst. Sci. 12, 1235-1254.

Drab, L., Hubert-Ferrari, A., Schmidt, S., Martinez, P., Carlut, J., El Ouahabi, M., 2014. Submarine earthquake history of the Cinarcık segment of the North Anatolian Fault in the Marmara Sea, Turkey. Bull. Seismol. Soc. Am. 105 (2a).

Dunlop, D., Özdemir, Ö., 1997. Rock Magnetism. Cambridge University Press (573 pp.).

Emeis, K.C., Robertson, A.H.F., Richter, C., et al., 1996. Paleoceanography and sapropel introduction. Proceedings ODP, Initial Report 160, pp. 85-123.

Emeis, K.C., Sakamoto, T., Wehausen, R., Brumsack, H., 2000. The sapropel record of the eastern Mediterranean Sea-results of Ocean Drilling Program Leg 160. Palaeogeogr. Palaeoclimatol. Palaeoecol. 158, 371-395.

Florindo, F., Roberts, A.P., Palmer, M.R., 2003. Magnetite dissolution in siliceous sediments. Geochem. Geophys. Geosyst. 4, 7.

Fornacciari, F., 2005. Cartographie des suintements froids en Mer de Marmara. Université de Perpignan, Collége de France (Master's thesis).

Garming, J., Bleil, U., Riedinger, N., 2005. Alteration of magnetic mineralogy at the sulfatemethane transition: analysis of sediments from the argentine continental slope. Phys. Earth Planet. Inter. 151, 290-308.

Gearing, P., Plucker, F., Parker, P., 1977. Organic carbon stable isotope ratios of continental margin sediments. Mar. Chem. 5, 251-266.

Halbach, P., Holzbecher, E., Reichel, T., Moche, R., 2004. Migration of the sulphatemethane reaction zone in marine sediments of the Sea of Marmara-can this mechanism be tectonically induced? Chem. Geol. 205, 73-82.

Hedges, J., Keil, R., Benner, R., 1997. What happens to terrestrial organic matter in the ocean? Org. Geochem. 27, 195-212.

Higgs, N., Thomson, J., Wilson, T., Croudace, I.W., 1994. Modification and complete removal of eastern Mediterranean sapropels by postdepositional oxidation. Geology 22 $423-426$.

Kidd, R., Cita, M.B., Ryan, W.B.F., 1978. Stratigraphy of eastern Mediterranean sapropel sequences recovered during DSDP leg 42a and their paleoenvironmental significance. Initial Rep. Deep Sea Drill. Proj. 42, 421-443.

Kirci-Elmas, E., Algan, O., Özkar-Öngen, Z., Struck, U., 2008. Palaeoenvironmental investigation of sapropelic sediments from the Marmara Sea: a biostratigraphic approach to palaeoceanographic history during the Last Glacial-Holocene. Turk. J. Earth Sci. 17, 129-168.

Korte, M., Constable, C.G., 2011. Improving geomagnetic field reconstructions for 0-3 ka Phys. Earth Planet. Inter. 188, 247-259.

Kotthoff, U., Pross, J., Müller, U., Peyron, O., Schmiedl, G., Schulz, H., Bordon, A., 2008. Climate dynamics in the borderlands of the Aegean Sea during formation of sapropel S1 deduced from a marine pollen record. Quat. Sci. Rev. 27, 832-845.

Kroon, D., Alexander, I., Little, M., Lourens, L.J., Matthewson, A., Robertson, A.H.F. Sakamoto, T., 1998. Oxygen isotope and sapropel stratigraphy in the eastern Mediterranean during the last 3.2 million years. Proceedings of the Ocean Drilling Program, Scientific Results 160, pp. 181-189.

Lambeck, K., Sivan, D., Purcell, A., 2007. Timing of the last Mediterranean Sea-Black Sea connection from isostatic models and regional sea-level data. The Black Sea Flood Question: Change in Coastline. Climate and Human Settlement. Springer, Heidelberg, pp. 797-808.

Langereis, C.G. Dekkers, MJ. 1999. Magnetic cyclostratigraphy: high-resolution dating in and beyond the Quaternary and analysis of periodic changes in diagenesis and sedimentary magnetism. In: Maher, B.A., Thompson, R. (Eds.), Quaternary Climates, Environments and Magnetism. Cambridge University Press, pp. 352-382.

Larrasoaña, J.C., Roberts, A.P., Stoner, J.S., Richter, C., Wehausen, R., 2003. A new proxy for bottom-water ventilation in the eastern Mediterranean based on diagenetically controlled magnetic properties of sapropel-bearing sediments. Palaeogeogr Palaeoclimatol. Palaeoecol. 190, 221-242.

Larrasoaña, J.C., Roberts, A.P., Hayes, A., Wehausen, R., Rohling, E.J., 2006. Detecting missing beats in the Mediterranean climate rhythm from magnetic identification of oxidized sapropels (Ocean Drilling Program Leg 160). Phys. Earth Planet. Inter. 156, 283-293.

Larrasoaña, J.C., Roberts, A.P., Musgrave, R., Gràcia, E., Piñero, E., Vega, M., Martnez-Ruiz, F., 2007. Diagenetic formation of greigite and pyrrhotite in gas hydrate marine sedimentary systems. Earth Planet. Sci. Lett. 261, 350-366.
Le Pichon, X., Sengör, A., Demirbag, E., Rangin, C., Imren, C., Armijo, R., Görür, N., Cagatay, N., Mercier de Lepinay, B., Meyer, B., SaatçIlar, R., Tok, B., 2001. The active main Marmara Fault. Earth Planet. Sci. Lett. 192, 595-616.

Ledu, D., Rochon, A., de Vernal, A., Barletta, F., St-Onge, G., 2010. Holocene sea ice history and climate variability along the main axis of the northwest passage, Canadian Arctic. Paleoceanography 25, 1-21.

Likens, G., Bormann, F., Johnson, N., 1981. Interactions between major biogeochemical cycles in terrestrial ecosystems. Some Perspectives of the Major Biogeochemical Cyclespp. 93-112

Liu, J., Zhu, R.X., Roberts, A.P., Li, S., Chang, J., 2004. High-resolution analysis of early diagenesis effects on magnetic minerals in post-middle-Holocene continental shelf sediments from the Korea Strait. J. Geophys. Res. 109, B03103.

Lourens, L.J., Antonarakou, A., Hilgen, F., Van Hoof, A., Vergnaud-Grazzini, C., Zachariasse, W., 1996. Evaluation of the Plio-Pleistocene astronomical timescale. Paleoceanography 11, 391-413.

Major, C., Goldstein, S., Ryan, W.B.F., Lericolais, G., Piotrowski, A., Hajdas, I., 2006. The coevolution of Black Sea level and composition through the last deglaciation and its paleoclimatic significance. Quat. Sci. Rev. 25, 2031-2047.

McClusky, S., Reilinger, R., Mahmoud, S., Ben Sari, D., Tealeb, A., 2003. GPS constraints on Africa (Nubia) and Arabia plate motions. Geophys. J. Int. 155, 126-138.

McHugh, C., Seeber, L., Cormier, M., Dutton, J., Çağatay, N., Polonia, A., Ryan, W.B.F., Gorür, N., 2006. Submarine earthquake geology along the North Anatolia Fault in the Marmara Sea, Turkey: a model for transform basin sedimentation. Earth Planet. Sci. Lett. 248, 661-684.

Meyers, P.A., 1994. Preservation of elemental and isotopic source identification of sedimentary organic matter. Chem. Geol. 114, 289-302.

Nijenhuis, I., de Lange, G., 2000. Geochemical constraints on Pliocene sapropel formation in the eastern Mediterranean. Mar. Geol. 163, 41-63.

O'Reilly, W., 1984. Rock and Mineral Magnetism. Blackie, Glasgow, p. 220

Okay, A., Demirbağ, E., Kurt, H., Okay, N., Kusçu, İ., 1999. An active, deep marine strike-slip basin along the North Anatolian fault in Turkey. Tectonics 18, 129-147.

Pälike, H., Shackleton, N.J., Röhl, U., 2001. Astronomical forcing in late Eocene marine sediments. Earth Planet. Sci. Lett. 193, 589-602.

Passier, H.F., Middelburg, J., van Os, B., De Lange, G., 1996. Diagenetic pyritization under eastern Mediterranean sapropels caused by downward sulfide diffusion. Geochim. Cosmochim. Acta 60, 751-763.

Passier, H.F., De Lange, G., Dekkers, M.J., 2001. Magnetic properties and geochemistry of the active oxidation front and the youngest sapropel in the eastern Mediterranean Sea. Geophys. J. Int. 145, 604-614.

Poulton, S., Krom, M., Raiswell, R., 2004. A revised scheme for the reactivity of iron (oxyhydr)oxide minerals towards dissolved sulfide. Geochim. Cosmochim. Acta 68, 3703-3715.

Reinholdsson, M., Snowball, I., Zillén, L. Lenz, C. Conley, D., 2013. Magnetic enhancement of Baltic Sea sapropels by greigite magnetofossils. Earth Planet. Sci. Lett. 366, $137-150$

Rey, D., Mohamed, K.J., Bernabeu, A., Rubio, B., Vilas, F., 2005. Early diagenesis of magnetic minerals in marine transitional environments: geochemical signatures of hydrodynamic forcing. Mar. Geol. 215, 215-236.

Roberts, A.P., Stoner, J.S., Richter, C., 1999. Diagenetic magnetic enhancement of sapropels from the eastern Mediterranean Sea. Mar. Geol. 153, 103-116.

Roberts, A.P., Chang, L., Rowan, C.R., Horng, C.S., Florindo, F., 2011. Magnetic properties of sedimentary greigite $\left(\mathrm{Fe}_{3} \mathrm{~S}_{4}\right)$ : an update. Rev. Geophys. 49, RG1002.

Rockwell, T., Barka, A., Dawson, T., Akyuz, S., Thorup, K., 2001. Paleoseismology of the Gazikoy-Saros segment of the North Anatolia Fault, northwestern Turkey: comparison of the historical and paleoseismic records, implications of regional seismic hazard, and models of earthquake recurrence. J. Seismol. 5, 433-448.

Rohling, E.J., Hilgen, F.J., 1991. The eastern Mediterranean climate at times of sapropel formation: a review. Geol. Mijnb. 70, 253-264.

Ryan, W.B.F., Pitman, W., Major, C., Shimkus, K., Moskalenko, V., Jones, G., Dimitrov, P., Gorür, N., Sakinc, M., Yüce, H., 1997. An abrupt drowning of the Black Sea shelf. Mar. Geol. 138, 119-126.

Sarı, E., Çağatay, M., 2006. Turbidites and their association with past earthquakes in the deep Çınarcık Basin of the Marmara Sea. Geo-Mar. Lett. 26, 69-76.

Sperling, M., Schmiedl, G., Hemleben, C., Emeis, K., Erlenkeuser, H., Grootes, P. 2003. Black Sea impact on the formation of eastern Mediterranean sapropel S1? Evidence from the Marmara Sea. Palaeogeogr. Palaeoclimatol. Palaeoecol. 190, 9-21.

Stein, R., Barka, A., Dieterich, J., 1997. Progressive failure on the North Anatolian Fault since 1939 by earthquake stress triggering. Geophys. J. Int. 128, 594-604.

Stoner, J.S., Richter, C., Roberts, A.P., 1998. Data report: high-resolution study of magnetic properties of sapropel-bearing sediments from Sites 966, 967, and 969, eastern Mediterranean Sea. Proceedings of the Ocean Drilling Program, Scientific Results 160, pp. 75-82.

Süß, J., 2007. Kultivierungsabhängige Analyse mikrobieller Gemeinschaften in Sapropelen des östlichen Mittelmeeres. Universität Oldenburg ( $\mathrm{PhD}$ thesis).

Tauxe, L., Kent, D., 1984. Properties of a detrital remanence carried by haematite from study of modern river deposits and laboratory redeposition experiments. Geophys. J. R. Astron. Soc. 76, 543-561.

Tema, E., Kondopoulou, D., 2011. Secular variation of the Earth's magnetic field in the Balkan region during the last eight millennia based on archaeomagnetic data. Geophys. J. Int. 186, 603-614.

Thomson, J., Higgs, N., Wilson, T., Croudace, I.W., De Lange, G., Van Santvoort, P.J.J., 1995. Redistribution and geochemical behavior of redox-sensitive elements around S1, the most recent eastern Mediterranean sapropel. Geochim. Cosmochim. Acta 59, $3487-3501$ 
Thomson, J., Mercone, D., De Lange, G., Van Santvoort, P.J.J., 1999. Review of recent advances in the interpretation of eastern Mediterranean sapropel S1 from geochemical evidence. Mar. Geol. 153, 77-89.

Tolun, L., Çăgatay, M., Carrigan, W., 2002. Organic geochemistry and origin of Late GlacialHolocene sapropelic layers and associated sediments in Marmara Sea. Mar. Geol. 190, 47-60.

Tryon, M., Henry, P., Çağatay, M., Zitter, T., Geli, L., Gasperini, L., Burnard, P., Bourlange, S., Grall, C., 2010. Pore fluid chemistry of the North Anatolian Fault Zone in the Sea of Marmara: a diversity of sources and processes. Geochem. Geophys. Geosyst. 11 (Q0AD03), 1-22.

Tryon, M., Henry, P., Hilton, D., 2012. Quantifying submarine fluid seep activity along the North Anatolian Fault zone in the Sea of Marmara. Mar. Geol. 315, 15-28.

Tucker, P., 1980. Stirred remanent magnetization: a laboratory analogue of postdepositional realignment. J. Geophys. Z. Geophys. 48, 153-157.

Van Santvoort, P., De Lange, G., Langereis, C.G., Dekkers, M.J., Paterne, M., 1997. Geochemical and paleomagnetic evidence for the occurrence of "missing" sapropels in eastern Mediterranean sediments. Paleoceanography 12, 773-786.

Vidal, L., Menot, G., Joly, C., Bruneton, H., Rostek, F., Çăgatay, M.N., Major, C., Bard, E., 2010. Hydrology in the Sea of Marmara during the last $23 \mathrm{ka}$ : implications for timing of Black Sea connections and sapropel deposition. Paleoceanography 25, PA1205.
Vlag, P., Kruiver, P., Dekkers, M.J., 2004. Evaluating climate change by multivariate statistical techniques on magnetic and chemical properties of marine sediments (Azores region). Palaeogeogr. Palaeoclimatol. Palaeoecol. 212, 23-44.

Weeks, R., Laj, C., Endignoux, L., Fuller, M., Roberts, A., Manganne, R., Blanchard, E., Goree, W., 1993. Improvements in long-core measurement techniques: applications in palaeomagnetism and palaeoceanography. Geophys. J. Int. 114, 651-662.

Wehausen, R., Brumsack, H., 2000. Chemical cycles in Pliocene sapropel-bearing and sapropel-barren eastern Mediterranean sediments. Palaeogeogr. Palaeoclimatol. Palaeoecol. 158, 325-352.

Yamazaki, T., Abdeldayem, A., Ikehara, K., 2003. Rock-magnetic changes with reduction diagenesis in Japan Sea sediments and preservation of geomagnetic secular variation in inclination during the last 30,000 years. Earth Planets Space 55, 327-340.

Ziegler, M., Jilbert, T., de Lange, G., Lourens, L.J., Reichart, G.J., 2008. Bromine counts from XRF scanning as an estimate of the marine organic carbon content of sediment cores. Geochem. Geophys. Geosyst. 9, Q05009.

Zijderveld, J., 1967. The natural remanent magnetizations of the Exeter volcanic traps (Permian, Europe). Tectonophysics 4, 121-153.

Zitter, T.A.C., Henry, P., Aloisi, G., Delaygue, G., Çăgatay, M.N., de Lepinay, B.M., Al-Samir M., Fornacciari, F., Tesmer, M., Pekdeger, A., Wallmann, K., Lericolais, G., 2008. Cold seeps along the main Marmara Fault in the Sea of Marmara (Turkey). Deep-Sea Res. 55, 552-570. 